\title{
Strategic satisficing: Civil-military relations and French intervention in Africa
}

\author{
Marc R. DeVore* \\ School of International Relations, University of St Andrews \\ ${ }^{*}$ Corresponding author. Email: mrd7@st-andrews.ac.uk
}

(Received 5 July 2018; revised 21 November 2018; accepted 14 January 2019; first published online 3 April 2019)

\begin{abstract}
Few issues are more important yet less understood than outside interventions in intra-state conflicts. Under what circumstances do intervening states further their interests and when, contrarily, do they plunge into quagmires? France is a critical case. It is, statistically, the world's second intervenor and earned the sobriquet of Africa's gendarme through frequent interventions in African wars. The ability of such a medium-sized state to intervene with greater regularity and ostensible success than larger powers raises questions about how France manages its interventions. Do French interventions draw on the French Army's distinctive 'school' of population-centric counterinsurgency, which emphasises the need to militarise governance in pursuit of comprehensive victories? Or do the French Fifth Republic's civil-military institutions encourage policymakers to carefully regulate force's employment in pursuit of limited ends? This study draws on declassified archives to test which approach most characterises French interventions. To preview my conclusions, strategic satisficing - the use of minimal force for short durations to produce satisfactory outcomes - distinguishes the Fifth Republic's interventions from other powers' practices and prior French counterinsurgencies. This particular form of interventionism enables France to influence a large number of intra-state conflicts and maintain a network of security agreements with African states.
\end{abstract}

Keywords: Civil-Military Relations; France; Counterinsurgency; Civil Wars; Intervention

\section{Introduction}

Great power interventions in intra-state conflicts are a defining characteristic of contemporary international relations. Civil wars and insurgencies are far more common than classic inter-state wars, meaning that contemporary armed forces frequently face non-state adversaries. France is a critical case within this context. French officers developed a distinctive 'school' of populationcentric counterinsurgency between the 1840s and 1960s that enriched subsequent AngloAmerican debates on the subject. France today continues to play a disproportionate role in intra-state wars and intervenes in more African civil wars than any other power. The question remains, however, as to whether France's success as Africa's self-proclaimed gendarme is rooted in counterinsurgency practices that reached maturity during the Algerian War or other dynamics generated by the Fifth Republic's civil-military institutions.

France's Army gradually developed a counterinsurgency 'school' from the 1840s onwards with characteristics distinct from other population-centric approaches. These practices evolved over the course of multiple conflicts and many distinct doctrines. They all, nevertheless, emphasise the need to militarise civil governance in pursuit of comprehensive victories won through protracted campaigns. They also share a common focus on separating insurgents from potentially supportive populations via population control and psychological warfare measures. French

(c) British International Studies Association 2019. 
counterinsurgency theory, finally, attributes a decisive tactical role to indigenous paramilitary forces and elite French units working in tandem.

While France's military still cherishes these practices, another factor shaping France's interventions in Africa are the French Fifth Republic's institutions. Recurrent civil-military crises drove the Fifth Republic's founders in 1958 to develop institutions to better control military operations. To this end, they appointed civilian proconsuls to oversee military campaigns, civilianised counterinsurgencies' non-military components, and exploited rivalries between parallel military staffs. Because these new institutions empower civilian policymakers to pursue their preferences, there are powerful reasons for anticipating that they have likewise transformed French interventions. This would likely express itself in strategic satisficing, which is the use of minimal amounts of military force, tightly coupled with diplomacy, to achieve satisfactory political outcomes.

This study assesses whether the military's deeply-ingrained counterinsurgency culture or the Fifth Republic's civil-military institutions shape French interventions. To preview my conclusions, institutions rather than organisational culture predominate. Contemporary French operations are thus driven by political leaders' quest to achieve satisfactory outcomes at minimal cost, rather than by highly autonomous military commanders seeking comprehensive victories through traditional counterinsurgency practices. This transformation in how France conducts counterinsurgencies, likewise, shapes France's international behaviour. Leaders' ability to carefully regulate how much military power they commit enables them to avoid open-ended commitments and achieve reasonable outcomes at affordable prices.

This, in turn, renders it less risky for France to intervene militarily in Africa than it would be for other industrialised democracies. Strategic satisficing - facilitated by institutions that maximise civilian control over the military - thus empowers France to play an outsized role as Africa's gendarme.

\section{France's counterinsurgency culture}

France's armed forces, along with their British counterparts, are credited with developing the 'population-centric' approach to counterinsurgency. Central to population centric counterinsurgency is the notion that controlling a potentially hostile population and preventing insurgents from interacting with that population is counterinsurgents' essential mission. France's armed forces gradually developed a distinctive repertoire of counterinsurgency practices beginning in the mid-1830s, when military leaders recognised the limited value of unrestricted violence for pacifying Algeria. Army efforts to apply notions of 'peaceful penetration' to conquer the Algerian Sahara however foundered practically and intellectually, leading frustrated field commanders to revert to more punitive methods. ${ }^{1}$

Much of France's subsequent imperial expansion consequently differed little in its brutality from that of other European states. ${ }^{2}$ A cadre of French officers nevertheless persisted that they could pacify territories with less naked force and more recourse to artifices to separate guerrillas from sympathetic populations. France's successive conquests in Indochina, Madagascar, and Morocco then enabled Marshals Joseph-Simon Gallieni and Hubert Lyautey to develop and apply a veritable counterinsurgency doctrine or method. ${ }^{3}$ Later challenges, ranging from combatting the Riff uprising and Great Druze Revolt in the 1920s, to fighting Cold War-era national liberation movements, provided ample scope for successive generations of French officers to further theorise about how to fight insurgencies.

\footnotetext{
${ }^{1}$ Benjamin Brower, A Desert Named Peace: The Violence of France's Empire in the Algerian Sahara, 1844-1902 (New York: Columbia University Press, 2009), pp. 27-89.

${ }^{2}$ Jacques Frémeaux, De quoi fut fait l'empire (Paris: CNRS, 2010), pp. 453-81.

${ }^{3}$ Michael Finch, A Progressive Occupation? The Gallieni-Lyautey Method and Colonial Pacification in Tonkin and Madagascar (Oxford: Oxford University Press, 2013), pp. 31-211.
} 
The Cold War-era counter-revolutionary warfare partisans Roger Trinquier and Charles Lacheroy thus drew on this intellectual legacy extending back to earlier theorists of imperial pacification. ${ }^{4}$ A uniquely French 'school' of counterinsurgency thus gradually extended roots within the French Army. This French variant of population-centric counterinsurgency differs from its British counterpart in its greater emphasis on: militarised civil governance; population controls and psychological warfare; indigenous paramilitary forces; and aggressive elite units. ${ }^{5}$

Key to the French approach was a belief that only field commanders can determine the political and military measures that are necessary to defeat an insurgency. French commanders recognised the primacy of political factors over military ones since the late nineteenth century, when Gallieni argued that 'the best means of pacifying [colonies] ... is through the combined impact of [military] force and political action'. ${ }^{6}$ Another officer, Lieutenant-Colonel David Galula, building on Gallieni's hypothesis calculated during the Algerian War that 'A revolutionary war is 20 per cent military and 80 per cent political. ${ }^{7}$ However, rather than holding military force tributary to civil reforms, French theorists stressed the need for military authorities to assume the functions normally performed by civilian agencies. ${ }^{8}$

The rationale for military supremacy was that only the armed forces possess the centralised authority and coercive force needed for a comprehensive counterinsurgency effort. As Gallieni argued, 'Only the military's organization of territories, with its accompanying close surveillance [of populations], is capable of penetrating [society] deeply enough to extirpate all surviving germs of rebellion.' ${ }^{9}$ Playing such a large role in civil administration invariably drew officers to assume duties beyond those narrowly associated with military operations. Writing in 1900, Lyautey argued that 'An army company is not only a military unit but, above all, a reservoir of: foremen, artisans, teachers, gardeners and agronomists. ${ }^{10}$ Over half a century later, the French army assumed an even greater range of civilian missions, including education, police duties, and health care.

Besides championing the need for military supremacy, French officers prioritised population control and psychological action. French doctrine held that populations, particularly colonial ones, are fundamentally apolitical and can be compelled through repressive institutions and material incentives to accept any regime's authority. Reflecting this mechanistic view of populations, Galula argued 'In any case, whatever the cause, there will be an active minority for the cause, a neutral majority, and an active minority against the cause. The technique of power consists of relying on the favorable minority in order to rally the neutral majority and to neutralize or eliminate the hostile minority. ${ }^{11}$ General André Beaufre expanded on this observation, arguing that counterinsurgencies are won by psychologically 'provoking a veritable civil war between

\footnotetext{
${ }^{4}$ Thomas Rid, 'The nineteenth century origins of counterinsurgency doctrine', Journal of Strategic Studies, 33:5 (2010), pp. 727-58.

${ }^{5}$ British theorists framed Britain's counterinsurgency practices as characterised by: (1) use of minimum force; (2) the military's employment in support of civil authorities; and (3) efforts to win the 'hearts and minds' of populations. In practice, British commanders frequently transgressed these prescriptions and varied in how they conducted their campaigns. Nevertheless, the British Army generally conducted counterinsurgencies in a less coercive and more political fashion than the French. Douglas Porch, Counterinsurgency: Exposing the Myths of the New Way of War (Cambridge: Cambridge University Press, 2013), pp. 246-88; Paul Dixon, “Hearts and minds”? British counter-insurgency from Malaya to Iraq', Journal of Strategic Studies, 32:3 (2009), pp. 353-81; Marc DeVore, 'A more complex and conventional victory: Re-visiting the Dhofar counterinsurgency, 1963-75', Small Wars and Insurgencies, 23:1 (2012), pp. 141-70; and Marc DeVore, 'The United Kingdom's last hot war of the Cold War (Oman)', Cold War History, 11:3 (2011), pp. 441-71.

${ }^{6}$ Joseph-Simon Gallieni, 'Principes de Pacification et d'Organisation', Bulletin Officiel de Madagascar et de ses Dépendences, 26 (1898), p. 165.

${ }^{7}$ David Galula, Counterinsurgency Warfare: Theory and Practice (Westport: Praeger, 2006 [orig. pub. 1964]), p. 63.

${ }^{8}$ Roger Trinquier, La guerre moderne (Paris: Economica, 2008 [orig. pub. 1961]), pp. 40-3.

${ }^{9}$ Gallieni, 'Principes de Pacification et d'Organisation', p. 170.

${ }^{10}$ Hubert Lyautey, 'Du role Colonial de l'Armée', Revue des Deux Mondes, 69:4 (1900), p. 318.

${ }^{11}$ Galula, Counterinsurgency Warfare, p. 53.
} 
populations that have rallied, supported by the [French] military, and those that are still dissident'. ${ }^{12}$ French practitioners recognised, however, that rallying populations is an incremental process whereby counterinsurgents patiently expand pacified zones. Gallieni warned his subordinates against excessive haste by referring to this form of participation as action lente or 'slow action'. ${ }^{13}$

French officers gradually developed institutions of mass surveillance and propaganda to expedite this process. The Army's colonial intelligence services and bureaux arabes, indeed, achieved such a degree of sophistication that French colonies arguably already constituted 'intelligence states' prior to the Second World War. ${ }^{14}$ The failed Indochina War of 1945-54, however, exposed officers to Marxist and Maoist techniques of indoctrination and population control. ${ }^{15}$ France's new generation of theorists incorporated these totalitarian practices into their existing repertoire, developing a 'technical-organizational approach ... close to systems analysis' for dominating populations. ${ }^{16}$ Propaganda campaigns rooted in crowd psychology and measures to encourage inhabitants to inform on one another were foundational to this revised approach. These techniques were institutionalised in the Centre for Training and Preparation in Counter-Guerrilla Warfare (CIPCG), the Urban Protection Dispositive (DPU), and psychological warfare organisations (the cinquièmes bureaux). ${ }^{17}$

French theorists extolled indigenous paramilitaries' value at the same time as they developed practices for separating populations from insurgents. Over time, France's military employed large numbers of auxiliaries, including: spahis, goums, moghazenis, harkis, partisans, militias, garde civile, and GMPRs. ${ }^{18}$ This propensity for indigenous forces has two explanations. One lies in auxiliaries' superior ability to track guerillas because of their 'more rustic and lighter' nature compared with regular forces. ${ }^{19}$ The second rationale lies in France's tactic of quadrillage ('gridding'), which employs large static forces to control population centres and transportation arteries. French counterinsurgency theorists from Gallieni to Beaufre argued that the incremental deployment of quadrillage across a territory constitutes a necessary precondition for French forces to 'rally' populations. ${ }^{20}$ Paramilitaries became essential because France's metropole never provided enough forces for these tasks. ${ }^{21}$

In addition to large numbers of mediocre quadrillage troops, French theorists argued that they needed elite infantry to pursue and destroy rebel bands. A veritable French obsession with guerrilla-hunting units can indeed be traced back to the early stages of France's conquest of Algeria. Unable to catch insurgents, Marshal Thomas-Robert Bugeaud formed fast-marching columns of 'picked' volunteers, supported by rugged pack mules and lightweight artillery, beginning in $1836 .{ }^{22}$ Bugeaud argued that only such units could employ his 'system of mobile and incessant

\footnotetext{
${ }^{12}$ André Beaufre, La guerre révolutionnaire: Les formes nouvelles de la guerre (Paris: Fayard, 1972), p. 78.

${ }^{13}$ Joseph-Simon Gallieni, Trois Colonnes au Tonkin (Paris: R. Chapelot, 1899), p. 156.

${ }^{14}$ Martin Thomas, 'Colonial states as intelligence states', Journal of Strategic Studies, 28:6 (2005), pp. $1033-60$.

${ }^{15}$ Paul Villatoux and Marie-Catherine Villatoux, La République et son armée face au 'péril subversif' (Paris: Les Indes Savants, 2005), pp. 207-368.

${ }^{16}$ Beatrice Heuser, 'The cultural revolution in counter-insurgency', Journal of Strategic Studies, 1:30 (2007), p. 155.

${ }^{17}$ Tramor Quemeneur, "La discipline jusque dans l'indiscipline": la désobéissance de militaires français en faveur de l'Algérie française', in Mohammed Harbi and Benjamin Stora (eds), La Guerre d'Algérie, 1954-2004 (Paris: Robert Laffont, 2004), pp. 173-6.

${ }^{18}$ Recrutement des Indigènes Nord-Africains et des Formations Auxiliaires de l'Afrique du Nord (Paris: Ministère de la Guerre, 1934); Christophe Cazorla, 'Le concept d'emploi des supplétifs dans la guerre d'Algerie', Revue historique des armées, 4 (2002), pp. 69-82.

${ }^{19}$ Colonel Fabre, La Tactique au Maroc (Paris: Charles-Lavauzelle, 1931), p. 212.

${ }^{20}$ Beaufre, La guerre révolutionnaire, p. 75.

${ }^{21}$ Paul Ely, 'Enseignements de la Guerre d'Indochine', trans. in Rand Memorandum RM-5271-PR (Santa Monica: Rand, 1967), pp. 54-64; Yoav Gortzak, 'Using indigenous forces in counterinsurgency operations: the French in Algeria, 19541962', Journal of Strategic Studies, 32:2 (2009), pp. 316-19.

${ }^{22}$ 'Le maréchal de camp BUGEAUD à M. le Maréchal ministre de la Guerre' (16 June 1836), repr. in Paul Azan (ed.), Par L'Epée et par la Charrue: Ecrits et Discours de Bugeaud (Paris: PUF, 1948), pp. 1-5.
} 
warfare' to triumph over guerrillas. ${ }^{23}$ Gallieni later theorised that rapid columns of this sort perform the action vive or 'energetic actions', such as destroying rebel bands, needed to complement the progressive pacification of territories through action lente. ${ }^{24}$

The task of pursuing and defeating mobile guerrillas across rugged terrain remains highly challenging for military organisations. Bugeaud's lightly equipped forces sought to achieve this by out-marching and outmaneuvering insurgents. Lyautey, however, argued that elite units must also harness emerging technologies. ${ }^{25}$ French elite forces thus inaugurated a tradition of capitalising on the most modern means of transportation to better come to grips with guerrillas, including gunboats in Tonkin, armored cars in Morocco, and helicopters in Algeria. Over time, the elite units and their novel technologies acquired a mythic status within France's Army. General Marcel Bigeard lyrically described the physical and moral characteristics of an elite airmobile unit of his day in the following terms: 'An agile, light, feline and maneuverable battalion that possesses an unshakeable faith.' ${ }^{26}$

France's counterinsurgency practices' long development ensured that they enjoyed widespread support within the military establishment. This does not signify, however, that all French field commanders embraced this 'French school' of population centric counterinsurgency. Marshall Philippe-Henri Pétain during the Riff War (1925-7) and General René Cogny in Indochina (1950-4), for example, sought to force their opponents to fight conventional combined-arms battles. Louis Archinard, meanwhile, employed a punitive and brutalising approach in Mali, executing hostages and displacing populations. ${ }^{27}$ Archinard, furthermore, imbibed his subordinates with this philosophy, ultimately inspiring Captain Paul Voulet's and Lieutenant Jules Chanoine's murderous romp across the Sahel in 1898-9. ${ }^{28}$

Aside from these exceptions, however, the French military's counterinsurgency culture remains widespread and deeply rooted. Scholars, indeed, trace a continuous intellectual tradition from Bugeaud's 1836 arrival in Algeria to Galula's writings after Algeria's independence in 1962. This tradition, moreover, embraced many of the French Army's leading lights throughout this period, including Antoine Huré, Georges Catroux and Jean-Jacques Mordacq, in addition to the Gallieni and Lyautey. ${ }^{29}$ Perhaps it is unsurprising under these circumstances that most French officers blamed the defeats in Indochina (1945-54) and Algeria (1954-62) on either the poor execution of tactics or political leaders' miscalculations rather than any inherent flaws with French counterinsurgency practices. Military leaders therefore continue to conceptualise counterinsurgencies in terms of this doctrinal repertoire of: militarising civil governance; population controls and psychological warfare; raising indigenous paramilitary forces; and aggressive attacks by elite units.

France's counterinsurgency 'school' not only remains popular in France, but disproportionately impacts Anglo-American debates as well. Jean Gottmann's chapter in Edward Mead's 1943 Makers of Modern Strategy set French practices apart as uniquely worthy of study. ${ }^{30}$ Translations of Jean Larteguy's novels then provided subsequent generations with a romanticised vision of anti-guerrilla operations. While Larteguy's fiction reached masses, didactic works spoke to more specialised readerships. Consequently, Trinquier's translated La Guerre Moderne exposed readers to France's population control measures and Galula's publication of Counterinsurgency

\footnotetext{
${ }^{23}$ 'Le général BUGEAUD à THIERS’ (27 June 1842) repr. in Azan (ed.), Par L’Epée et par la Charrue, pp. 136-7.

${ }^{24}$ Gallieni, Trois Colonnes au Tonkin, pp. 156-7.

${ }^{25}$ Lyautey, 'Du role Colonial de l'Armée', p. 310.

${ }^{26}$ Marcel Bigeard, Pour une parcelle de gloire (Plon: Paris, 1975), p. 102.

${ }^{27}$ Albert Lorofi, La vie quotidienne des officiers de l'infanterie de marine pendant la conquête de la colonie du Soudan français (Paris: L'Harmattan, 2008), pp. 67-74.

${ }^{28}$ Bertrand Taithe, The Killer Trail: A Colonial Scandal in the Heart of Africa (Oxford: Oxford University Press, 2009).

${ }^{29} \mathrm{Rid}$, 'The nineteenth century origins of counterinsurgency doctrine'; Finch, A Progressive Occupation?, pp. 230-7.

${ }^{30}$ Jean Gottmann, 'Bugeaud, Galliéni, Lyautey: the development of French colonial warfare', in Edward Earle (ed.), Makers of Modern Strategy: Military Thought from Machiavelli to Hitler (Princeton: Princeton University Press, 1943), pp. 234-59.
} 
Warfare in English provided a distillation of French counterinsurgency thought. ${ }^{31}$ Publication in English set Galula and Trinquier up to re-emerge as the only non-British or American authors referenced in the 2006 U.S. Army/Marine Corps Counterinsurgency Field Manual. ${ }^{32}$

\section{Counterinsurgencies and civil-military crises}

Although France's distinctive counterinsurgency practices enjoyed widespread support within the military establishment, the Fifth Republic's political leaders considered these same practices inimical to civilian control of the nation's armed forces. Campaigns of colonial pacification all too often escaped the control of France's democratically elected leaders, saddling them with unwanted conquests and military commitments. The French military's further evolution of counterinsurgency doctrine later contributed to civil-military crises during France's wars of decolonisation.

Experts have long recognised that expeditionary counterinsurgency operations are corrosive to good civil-military relations and have advanced three arguments explaining why. The problem lies, for principle-agent theory's proponents, in the difficulty that political 'principals' face in controlling their military 'agents' when the latter conduct complex counterinsurgency operations abroad. ${ }^{33}$ According to a second group of scholars, counterinsurgencies tempt armed forces to substitute their authority for that of their civilian masters by gradually eroding clear distinctions between military and civilian roles. ${ }^{34}$ A third group contends that 'internal security' doctrines prompt military interventions in politics by redefining the armed forces' missions to include such intangible goals as defending a nation's moral health. ${ }^{35}$ Civil-military scholars thus agree that counterinsurgencies undermine civilian leaders' control over their armed forces although they differ on exactly why this occurs.

However, as will be shown, French armed forces' distinctive practices aggravated the civilmilitary tensions that counterinsurgencies produce. For example, while civilian leaders invariably have trouble evaluating counterinsurgency operations because of the absence of clear metrics for measuring success, this quandary was accentuated in France by the armed forces' insistence that autonomous commanders should wield supreme authority over all of counterinsurgencies' military and civilian components. Expressing this normative belief, Lyautey asserted that, 'The first act of any commanding general operating at 3,000 leagues [from the homeland] should be to cut the telegraph wire to free himself from the metropole's harassing instructions. ${ }^{36}$

French field commanders often abused the autonomy conferred upon them to pursue agendas at variance with their orders. A. S. Kanya-Forstner, for example, demonstrates how careerism and pro-colonial ideologies drove nineteenth-century commanders to overstep their mandates and conquer territories that were neither profitable nor desired by France's government. ${ }^{37}$ Lyautey, likewise, sparked an international crisis that nearly led to a European war with his unauthorised occupation of Moroccan territory. ${ }^{38}$ These abuses, grave as they are, pale in comparison with

\footnotetext{
${ }^{31}$ Bertrand Valeyre and Alexandre Guérin, De Galula à Petraeus, l’héritage français dans la pensée américaine de la contre-insurrection (Paris: CDEF, 2009), pp. 24-55.

${ }^{32}$ The U.S. Army/Marine Corps Counterinsurgency Field Manual (Chicago: University of Chicago Press, 2007).

${ }^{33}$ Peter Feaver, Armed Servants: Agency, Oversight, and Civil-Military Relations (Cambridge, MA: Harvard, 2003).

${ }^{34}$ Samuel Huntington, The Soldier and the State: The Theory and Politics of Civil-Military Relations (Cambridge, MA: Harvard University Press, 1998); Charles Dunlap, 'The origins of the American military coup of 2012', Parameters (winter 1992-3), pp. 2-20.

${ }^{35}$ Michael Desch, Civilian Control of the Military (Baltimore: Johns Hopkins, 1999).

${ }^{36}$ 'Lyautey à sa sœur' (9 February 1895), cited in Maxime Gillet, Principes de Pacification du Maréchal Lyautey (Paris: Economica, 2010), p. 63.

${ }^{37}$ A. S. Kanya-Forstner, The Conquest of the Western Sahara: A Study in French Military Imperialism (Cambridge: Cambridge University Press, 1969).

${ }^{38}$ Kim Munholland, 'Rival approaches to Morocco: Delcassé, Lyautey, and the Algerian-Moroccan border', French Historical Studies, 5:3 (1968), pp. 328-43.
} 
commanders' actions during the 1954-62 Algerian War. Field commanders twice sabotaged government efforts to negotiate an end of the war, first by intercepting the aircraft carrying rebel leaders to peace negotiations in 1956 and, second, by bombing a village in Tunisia in $1958 .{ }^{39}$ France's commander in Algeria, Raoul Salan, exploited the domestic upheaval following the latter incident to overthrow France's Fourth Republic.

The French military's population control and psychological warfare practices provided officers with both a rationale and tools for further intervening in politics. To counter insurgents' calls to fight for independence, military propagandists promised to fully integrate Muslim Algerians into French political life and dramatically raise their standard of living. Successive governments' unwillingness to commit themselves to this objective - or indeed offer an unambiguous vision of the future - prompted officers to impose their preferences on the government. ${ }^{40}$ Their counterinsurgency techniques, meanwhile, widened the range of tools they possess for shaping public opinion and governance. ${ }^{41}$ The officers who plotted the May 1958 coup, for example, merely turned the techniques and institutions of psychological action against France's elected government. In one example, Trinquier employed the DPU, originally developed for ferreting out terrorists, to mobilise Algeria's population against its elected leaders. ${ }^{42}$ Afterwards, proponents of psychological action and population control, such as colonels Antoine Argoud, Charles Lacherory, and Yves Godard, directed the 1961 coup attempt against Charles de Gaulle and then led the Organisation Armée Secrète's terror campaign. ${ }^{43}$

Even France's heavy use of paramilitary forces contributed to its civil-military problems. Officers developed deep emotional ties with the local paramilitaries they led and felt personally responsible for their well-being. Such bonds generated conflicting loyalties whenever French governments adopted policies prejudicial to auxiliaries' interests. ${ }^{44}$ Officers who served with local auxilliaries, for example, were more likely to participate in the 1958 and 1961 putsches in Algeria than those who did not. ${ }^{45}$ Hélie de Saint Marc, one of the 1961 putsch's participants, expressed this sentiment when he wrote, 'When General Challe spoke to me [about joining the putsch], I remembered ... the day in 1948 when I agreed to lead partisans from Talung [in Indochina] and again felt my disgrace [about abandoning them] ... A man who consciously betrays other men is a criminal. ${ }^{46}$

The elite paratroop and Foreign Legion units that played prominent roles in France's counterinsurgency doctrine also spearheaded the military's interventions into politics. These units' continuous engagement in mobile anti-guerrilla operations severed their contact with civil society. The Foreign Legion's professional nature and its soldiers' cosmopolitan backgrounds exacerbated this problem further, rendering soldiers liable to uncritically follow officers into political adventures. ${ }^{47}$ French elite soldiers therefore developed belief systems that elevated military considerations over obedience to political leaders and transformed France's elite into the praetorian 'lost soldiers' that overthrew the Fourth Republic and nearly did likewise to its successor. ${ }^{48}$

In sum, France's distinctive counterinsurgency practices undermined civilian leaders' control of the armed forces. Military commanders consequently pursued private objectives at the expense of

\footnotetext{
${ }^{39}$ Irwin Wall, 'De Gaulle, the “Anglo-Saxons” and the Algerian war', Journal of Strategic Studies, 25:2 (2002), pp. 118-37.

${ }^{40}$ Raoul Girardet, 'Civil and military power in the Fourth Republic', in Samuel Huntington (ed.), Changing Patterns of Military Politics (New York: Free Press, 1962), pp. 135-9.

${ }^{41}$ George Kelly, Lost Soldiers: The French Army and Empire in Crisis, 1947-1962 (Cambridge: MIT, 1965).

${ }^{42}$ Pierre Abramovici, Le Putsch des Généraux: De Gaulle contre l'armée 1958-1961 (Paris: Fayard, 2011), pp. $72-88$.

${ }^{43}$ Quemeneur, “'La discipline jusque dans l'indiscipline”, pp. 173-9.

${ }^{44}$ Philippe Pottier, 'GCMA/GMI: A French experience in counterinsurgency during the French Indochina War', Small Wars \& Insurgencies, 16:2 (2005), pp. 125-46.

${ }^{45}$ Paul-Marie de La Gorce, La République et son Armée (Paris: Fayard, 1963), p. 654.

${ }^{46}$ Hélie de Saint Marc, Mémoire: Les champs de braises (Paris: Perrin, 1995), p. 265.

${ }^{47}$ Eckard Michels, 'From one crisis to another: the morale of the French Foreign Legion during the Algerian War', in Martin Alexander et al. (eds), The Algerian War and the French Army, 1954-62 (Basingstoke: Palgrave, 2002), pp. 96-9.

${ }^{48}$ Quemeneur, “La discipline jusque dans l'indiscipline”, p. 176; Abramovici, Le Putsch des Généraux, p. 284.
} 
the government's foreign policy during the late nineteenth and early twentieth centuries' campaigns of imperial pacification. These same counterinsurgency practices later turned parts of the armed forces into a danger to French democracy during the Algeria War. In short, although counterinsurgencies frequently strain civil-military relations, France's practices were particularly deleterious and provoked the most serious civil-military crises experienced by an advanced modern democracy.

\section{Civil-military control institutions}

French leaders considered the armed force's counterinsurgency practices a threat from the Fifth Republic's foundation in 1958. It was in the name of counterinsurgency doctrine, indeed, that some of France's most decorated officers and premier units overthrew the Fourth Republic, attempted to overthrow the Fifth, and waged a terrorist campaign against the state. De Gaulle's new government ensured itself against any recurrence of France's civil-military crises by developing institutions to curtail the armed forces' autonomy and by subjecting them to an unprecedented degree of political control.

De Gaulle personally believed that the key to viable civil-military relations lay in reorienting France's army from population-centred counterinsurgency to conventional military operations. De Gaulle told close collaborators towards the Algerian War's conclusion that, 'That's enough with colonial wars. We are having all the problems in the world extricating ourselves from the one in Algeria [1954-62] and I do not want to engage in a new one. ${ }^{, 49}$ He therefore enjoined officers to shift their intellectual focus from counterinsurgency to the combined arms manoeuvres and tactical nuclear strikes needed to defend against the Soviet Union. De Gaulle told colleagues repeatedly that he would 'return the army to the Rhine' and 'end the [army's] focus on Algeria'. ${ }^{50}$ De Gaulle, therefore, reconfigured most of the Army for high-intensity warfare and promoted atomic strategists, such as Charles Ailleret and Paul Stehlin, at the expense of counterinsurgency specialists. ${ }^{51}$

French foreign policy, however, precluded an exclusive focus on the Soviet threat. De Gaulle's desire to preserve France's African sphere of influence - codified in military cooperation agreements concluded with all of France's sub-Saharan ex-colonies except Guinea - obliged France to intervene in more African conflicts than any other power. ${ }^{52}$ France's 1972 Defense White Paper articulated France's intervention doctrine, by defining French overseas interests in Africa as the 'third circle' of French security, whose defence would be guaranteed by military units permanently deployed to African bases. ${ }^{53}$ This policy ensured, however, that France's armed forces would again fight insurgents far away from France's metropole since intra-state conflicts pose the primary threat to this third circle. ${ }^{54}$

De Gaulle and his colleagues recognised how detrimental prior counterinsurgencies had been to French civil-military relations and wanted to avoid any recurrence of past problems. They therefore developed four institutional strategies for better controlling the armed forces during interventions. These include: (1) the creation of a powerful civilian Secretariat in Paris; (2) the appointment of special ambassadors to oversee interventions; (3) civilianising interventions' noncombat functions; and (4) creating parallel military staffs to maximise civilian leaders' options.

\footnotetext{
${ }^{49}$ Guia Migani, La France et l'Afrique sub-saharienne, 1957-1963 (Brussels: PIE Peter Lang, 2008), p. 135.

${ }^{50}$ Roger Belin, Lorsqu'une République chasse l'autre (Paris: Michalon, 1999), pp. 113-17; de La Gorce, La République et son Armée, pp. 670-2.

${ }^{51}$ Sten Rynning, Changing Military Doctrine: Presidents and Military Power in Fifth Republic France, 1958-2000 (Westport: Praeger, 2002), pp. 23-63; Marc DeVore, 'Armed forces, states and threats: Civil-military institutions and military power in modern democracies’, Comparative Strategy, 31:1 (2012), pp. 59-61; and Kelly, Lost Soldiers, pp. 344-5.

${ }^{52}$ Chester Crocker, 'France's changing military interests: Evolution of the "most potent external military factor" in contemporary Africa', Africa Report (June 1968), p. 20.

${ }^{53}$ Livre Blanc sur la Défense Nationale (Paris: Ministère de la Défense, 1972).

${ }^{54}$ Frédéric Turpin, Jacques Foccart: Dans l'ombre de pouvoir (Paris: CNRS, 2015), pp. 208-12.
} 
The first strategy involved designating civilian, rather than military leaders, to oversee military interventions' political and military facets. De Gaulle inaugurated this policy during the Algerian War in 1958 by appointing civilian fonctionnaire Paul Delouvrier to replace General Salan as France's proconsul in Algeria. ${ }^{55}$ Although de Gaulle viewed Delouvrier's appointment as a temporary expedient, he also developed more permanent structures to ensure a similar level of oversight over future interventions in sub-Saharan Africa.

To this end, he established a General Secretariat for African and Malagasy Affairs staffed by 150 personnel. ${ }^{56}$ Institutionally, de Gaulle's creation of this Secretariat set France's Africa policy apart from its policies towards other continents by subordinating the former directly to France's Presidency while the Foreign Ministry oversaw the latter. De Gaulle reinforced the Secretariat's importance by appointing one of his closest collaborators, Jacques Foccart, to oversee it in $1960 .{ }^{57}$ Foccart's discretion and loyalty earned him unrivalled access to de Gaulle, including daily meetings, after de Gaulle's ascension to the Presidency. Foccart's stature thus ensured that the position of the French President's General Secretary for African and Malagasy Affairs, otherwise known as the President's 'Monsieur Afrique', would remain powerful under his successors.

Foccart and his Secretariat drew on a repertoire of institutions and procedures for managing interventions. The Secretariat benefited from its outset from a close partnership with the French intelligence service's section specialising in African affairs (Sector ' $N$ ' of the SDECE) ${ }^{58}$ Through both Sector $\mathrm{N}$ and his own personal networks, Foccart orchestrated clandestine activities, ranging from coups to mercenary operations, without calling upon France's regular military. Foccart and his successors also appointed handpicked 'special' ambassadors for states whenever the local political situation deteriorated beyond a certain threshold. ${ }^{59}$ French governments could then give these ambassadors pro-consular authority over military forces in the eventuality of French interventions. ${ }^{60}$

French leaders' third institutional strategy for controlling future military interventions was narrowly circumscribing the armed forces' role. Whereas soldiers hitherto undertook many functions normally performed by civilian bodies, France's government now 'civilianised' counterinsurgencies' non-combat components. To this end, they administratively separated counterinsurgencies' military and political aspects, and entrusted the latter to civil service personnel. ${ }^{61}$ This role differentiation limited the armed forces' responsibility for interventions' outcomes and their contact with local populations.

The government's fourth new mechanism was a 'divide and rule' system embodied in parallel inter-service military staffs that maximise political leaders' ability to control interventions from Paris. In addition to the armed forces' Joint Staff (EMA), France's president controls his private military staff (EMP), the prime minister seeks military advice from his general secretariat for national defence (SGDN) and the minister of defence solicits options from his military cabinet. Thus, rather than dealing with a monolithic military hierarchy, rival inter-service staffs generate multiple recommendations and enable political leaders to select those options most consonant with their preferences. ${ }^{62}$

\footnotetext{
${ }^{55}$ Abramovici, Le Putsch des Généraux, pp. 84-90.

${ }^{56}$ Pascal Geneste, 'Jacques Foccart ou la politique africaine de la France gaullienne', in Philippe Oulmont and Maurice Vaïsse (eds), De Gaulle et la décolonisation de l'Afrique subsaharienne (Paris: Karthala, 2014), pp. 190-4.

${ }^{57}$ Turpin, Jacques Foccart, pp. 39-75, 185-226.

${ }^{58}$ Roger Faligot et al., Histoire politique des services secrets français de la Seconde Guerre mondiale à nos jours (Paris: La Découverte, 2012), pp. 225-42.

${ }^{59}$ John Chipman, French Power in Africa (Oxford: Blackwell, 1989), pp. 232-6.

${ }^{60}$ Author's interview with Ambassador Fernand Wibaux, Paris, 18 February 2005.

${ }^{61}$ Turpin, Jacques Foccart, pp. 135-42, 188-9.

${ }^{62}$ Samy Cohen, La défaite des généraux: Le pouvoir politique et l'armée sous la Ve République (Paris: Fayard, 1994); Jean Guisnel, Les généraux: Enquête sur le pouvoir militaire en France (Paris: La Découverte, 1990).
} 
There are powerful reasons for anticipating that the enhanced civilian control that these institutions were designed to achieve would also alter the French interventions' fundamental character. A long tradition of social science research demonstrates that civilian policymakers possess preferences different from those of military commanders on how to employ force. ${ }^{63}$ In contrast to military leaders' preference for employing maximum force to achieve decisive victories, political decision-makers are rarely willing to spend more economic or military capital than needed to obtain a high probability of success. As one scholar observed, military commanders prefer to optimise the probability of victory through overwhelming force, while civilian leaders tend to 'satisfice' by reducing commitments to the minimal levels needed to attain their goals. ${ }^{64}$ The type of war that states wage thus depends on whose preferences - political leaders' or military commanders' - prevail when it comes to designing a campaign.

As Deborah Avant demonstrates, variations between states' political institutions shape politicians' ability to impose their preferences. ${ }^{65}$ De Gaulle's development of sweeping civil-military control institutions, within this context, should logically result in operations reflecting their desiderata to an exceptional degree. As a result, rather than seeking victory, national leaders are likely to limit their aims to advancing narrowly defined interests. Since intervening states can frequently achieve objectives such as reassuring allies and deterring rivals without winning decisively, the Fifth Republic's leaders can be expected to minimise the resources they commit and to guard against open-ended engagements. Political leaders' propensity for strategic satisficing leads them to intersperse military operations with diplomatic negotiations because continuous communication is a prerequisite for resolving conflicts in the absence of military victory. ${ }^{66}$

In sum, the Fifth Republic's founding leaders developed institutions to enhance civilian control over military operations. They attempted this by: appointing civilian proconsuls to oversee interventions, civilianising counterinsurgencies' non-military components, and exploiting rivalries between parallel inter-service staffs. These institutions will, if successful at their original objective, likely alter the fundamental nature of French counterinsurgencies. Operations would, in theory, be characterised by civilian proconsuls overseeing the combined use of diplomacy and minimal force to achieve limited objectives. However, the question remains as to whether French military culture or policymaking institutions exercise a greater impact on the Fifth Republic's counterinsurgencies since the military establishment's existing practices clash with the Fifth Republic's civil-military dynamics.

\section{Case selection}

France's armed forces' ingrained counterinsurgency practices and the Fifth Republic's civilmilitary institutions yield very different predictions about how France's Fifth Republic conducts counterinsurgencies. Perhaps nowhere are these distinctions starker than on the twin questions of who - civilian or military leaders - controls interventions and whether they will conduct brief or protracted campaigns. If military culture is the most important factor, then recent French counterinsurgencies should strongly resemble preceding ones, with military proconsuls progressively pacifying rebellious territories. If the Fifth Republics civil-military institutions are predominant, then different dynamics of political micromanagement and strategic satisficing should prevail.

Besides differing on counterinsurgencies' direction and duration, military culture and civilmilitary institutions suggest different mechanisms for France to achieve its objectives.

\footnotetext{
${ }^{63}$ Richard Betts, Soldiers, Statesmen and Cold War Crises (New York: Columbia University Press, 1991 [orig. pub. 1977]).

${ }^{64}$ Herbert Simon coined the term 'satisficing' in 1956 to denote decision-making strategies that seeks adequate, rather than optimal solutions to problems. This notion challenges traditional economists' view of 'value maximising' rationality.

${ }^{65}$ Deborah Avant, 'The institutional sources of military doctrine: Hegemons in peripheral wars', International Studies Quarterly, 37:4 (1993), pp. 409-30.

${ }^{66}$ Raoul Castex, 'Les liens des diverses stratégies (un cas concret)', Revue des Questions de Défense Nationale, 1:1 (1939), pp. $45-73$.
} 
De Gaulle designed the Fifth Republic's civil-military institutions to facilitate the closely coupled application of diplomacy and military force. Policymakers can be expected, under these circumstances, to employ careful doses of limited forces to reassure allies and coerce enemies into negotiating. The French militaries' counterinsurgency culture, contrarily, privileges the gradual, yet inexorable application of action lente to pacify populations and action vive to annihilate recalcitrant guerrilla bands. The military, within this context, achieves victory by spreading a network of quadrillage forces across a territory and then subjecting inhabitants to population control and psychological warfare campaigns.

French scholars themselves disagree about whether civil-military institutions or military culture plays a greater role. Vincent Joly and Raphaël Granvaud emphasise continuities between earlier counterinsurgencies and France's recent African interventions. ${ }^{67}$ Samy Cohen and Jean Guisnel, contrarily, contend that the Fifth Republic's institutions promote civilian micromanagement of military operations. ${ }^{68}$

Answering this question about how France conducts counterinsurgencies has powerful implications for scholars and policymakers alike. France has, by any measure, conducted more military interventions than any state, besides the United States, since the Second World War. The most authoritative list chronicles 309 distinct French military operations conducted abroad since $1945 .^{69}$ Many of these operations were small, ranging from disaster relief to evacuating French citizens from conflict zones. France is nonetheless remarkably militarily proactive, even taking into account the large numbers of small operations.

French interventionism is particularly significant for sub-Saharan Africa, which accounts for 44 per cent of France's interventions. ${ }^{70}$ France's propensity for African interventions and other states hesitancy to engage in Africa makes France sub-Saharan Africa's most important external security actor. French forces, indeed, played a key role at many critical junctures, from suppressing a 1977-8 uprising threatening Zaire's President Mobutu Sese Seko to driving al-Qaeda from Timbuktu in 2013. Table 1 below illustrates the 14 African counterinsurgency operations France conducted under the Fifth Republic. ${ }^{71}$

The frequency and effectiveness of France's interventions lead many to regard France as Africa's de facto gendarme. ${ }^{72}$ Understanding how a medium-sized country like France intervenes militarily so often at so little political or economic cost to itself is thus of a more general interest to International Relations scholars.

Evaluating the relative impact of military culture and civil-military institutions on France's African interventions is, however, unavoidably complex because of the need to ascertain both the nature of what France did as well as the policymaking process that resulted in those actions. Accomplishing this within an article's confines privileges a single case study rather than addressing multiple cases in insufficient detail. Arguably, France's 1969-72 intervention in Chad stands out as an ideal case study for this endeavour because of its unique combination of representativeness, salience, and available sources.

In terms of representativeness, the 2,851 personnel committed to this intervention place it exceptionally close to the mean (2,831 personnel) for the African counterinsurgencies involving

\footnotetext{
${ }^{67}$ Vincent Joly, Guerres d'Afrique: 130 ans de guerres coloniales, L'expérience française (Rennes: PUR, 2009); Raphaël Granvaud, Que fait l'armée française en Afrique? (Marseilles: Agone, 2009).

${ }^{68}$ Cohen, La défaite des généraux, pp. 123-48.

${ }^{69}$ Opérations militaires: de 1945 à nos jours, available at: \{http://jgrattepanche.free.fr/\} accessed 17 August 2018.

${ }^{70}$ France intervened in sub-Saharan Africa 135 times, which far exceeds its operations in Europe (50), the Near East (46), the Middle East (17), or the Caribbean (16).

${ }^{71}$ This list excludes missions conducted under international organisations' auspices. Data from Opérations militaires: de 1945 à nos jours is supplemented in this table by: Pierre Dufour, La France au Tchad depuis 1969 (Boulogne-Billancourt: ETAI, 2009); and Nicolas Rey, 50 ans d'OPEX en Afrique (Paris: CDEF, 2015).

${ }^{72}$ Victor-Manuel Vallin, 'France as the Gendarme of Africa, 1960-2014', Political Studies Quarterly, 130:1 (2015), pp. 79100
} 
Table 1. Fifth Republic interventions in African civil wars.

\begin{tabular}{llll}
\hline Dates & Name(s) of Operation & Location & Personnel \\
\hline $1958-9$ & Op. Ecouvillon & Western Sahara & 5,000 \\
\hline $1969-72$ & Op. Limousin & Chad & 2,851 \\
\hline $1977-80$ & Op. Lamantin & Mauritania & $350^{\star}$ \\
\hline $1977-8$ & Ops Verveine/Bonite & Zaire & $400^{\star}$ \\
\hline $1978-82$ & Op. Tacaud & Chad & 2,600 \\
\hline $1983-4$ & Op. Manta & Chad & 3,500 \\
\hline $1986-2014$ & Op. Epervier & Chad & 3,000 \\
\hline $1990-3$ & Op. Noroit & Rwanda & 300 \\
\hline 1996 & Ops Almandin 1-3 & Central African Republic & 2,500 \\
\hline $1998-9$ & Op. Iroko & Guinea-Bissau & 74 \\
\hline $2002-15$ & Op. Licorne & Ivory Coast & 5,000 \\
\hline $2003-p r e s e n t$ & Op. Boali & Central African Republic & 300 \\
\hline $2013-14$ & Op. Serval & Mali & 4,000 \\
\hline $2013-16$ & Op. Sangaris & Central African Republic & 2,000 \\
\hline
\end{tabular}

Note: *Signifies that statistics include only ground forces.

combat by French ground forces. ${ }^{73}$ This intervention is also particularly salient today because of France's rediscovery of it as a 'successful' counterinsurgency. Colonel Michel Goya, indeed, argues in official publications and popular magazines alike that France conducted an 'exemplary counterinsurgency' and won a 'forgotten victory' in Chad. ${ }^{74}$

France's 1969-72 Chad intervention offers additional advantages as a case study in terms of the range of primary sources accessible. Triangulation among different categories of documents is invaluable when it comes to penetrating civil-military planning processes that are rarely articulated in memoirs. Declassifications, within this context, enable me draw on four categories of documents, including: military documents accessed at France's Service Historique de la Défense (SHD); the military's internal study, Les Interventions Militaires Françaises au Tchad (IMFT); French diplomatic documents from Documents Diplomatiques Français (DDF); and external British assessments from The National Archives (TNA). I further draw on published Chadian and French journals and interviews conducted with France's former ambassador to Chad to provide the most comprehensive account yet of this intervention.

In sum, France's 1969-72 Chad intervention constitutes the best case for assessing whether the military's counterinsurgency culture or the Fifth Republic's institutions play a greater role in shaping French interventions in African conflicts. This article tests these hypotheses by successively examining four phases of France's intervention where civilian and military preferences clashed, including: France's initial decision to intervene, how France structured its intervention, how decision-makers integrated diplomatic and military initiatives, and finally how France's government disengaged its forces. A subsequent section then assesses whether conclusions drawn from this case hold true for subsequent interventions despite communications technologies' development and the French public's increasingly positive opinion of their armed forces.

\footnotetext{
${ }^{73}$ Operations Iroko, Noroit, and Lamantin are excluded based on this criteria.

${ }^{74}$ Michel Goya, 'La victoire oubliée', Combats et Opérations, 5 (2013), pp. 12-19.
} 


\section{Choosing to intervene}

France's colonial policies and miscalculations by Chad's post-independence leaders sparked an insurgency that engulfed Chad by 1968 and threatened to overthrow the government. Because Chad's borders are the product of competing French, Anglo-Egyptian, and Italian imperialisms, the state encompasses three distinct populations - Christian/animist farmers, Muslim farmers, and Muslim nomads - each of which includes numerous tribes. ${ }^{75}$ The colonial state's burdens of compulsory labour and military conscription, however, fell heaviest on the Christian/animist Sara ethnicity of southern Chad. ${ }^{76}$ It was one of these Sara, François Tombalbaye, who won the presidential elections France organised as it withdrew and then exploited his newfound power to redistribute resources to his own people. ${ }^{77}$

Discriminatory policies and excessive taxation drove Chadian Muslims to revolt in 1965. Chad's 3,000 soldiers responded by burning villages and slaughtering livestock, which only drove more Chadians to join the rebellion. ${ }^{78}$ Exiles, foremost among whom was Ibrahim Abatcha, federated this emerging resistance under the aegis of the Front de Liberation Nationale du Tchad (Chad Liberation Front or FROLINAT). ${ }^{79}$ The traditional leader of northern Chad's nomadic Tubu ethnic group, the Derdeï meanwhile entered into dissidence in $1966 .{ }^{80}$ Foreign support - from North Korea, Egypt, Syria, and Sudan - then fuelled FROLINAT's growth such that only Tombalbaye's ethnic power base in southern Chad remained loyal by mid-1968. ${ }^{81}$

The process by which France came to intervene in this conflict witnessed the systematic elevation of civilian over military expertise, and the privileging of diplomatic over tactical considerations. French political leaders initially had little desire to intervene because Chad was one of France's poorest ex-colonies and its hostile terrain and warlike inhabitants led many to consider the country a quagmire. Francophone African leaders, however, urged de Gaulle to support Tombalbaye because they viewed Chad as a test of whether France would uphold its commitments to other allies. Madagascar's President Philibert Tsiranana and Niger's Hamani Diori led the way in trying to persuade French leaders that their African allies would lose faith in France's security guarantees if France refused to intervene. ${ }^{82}$

Tombalbaye, for his part, openly courted other partners. After failing to convince the superpowers to provide aid, Tombalbaye found an eager supporter in Israel. Israel provided development assistance from 1964 onwards in exchange for Chadian diplomatic support at the United Nations. ${ }^{83}$ Israeli leaders later expanded their aid programme to win Tombalbaye's support for efforts to destabilize its enemies by supplying arms to Sudan's Anya-Nya rebels and sponsoring Prince Abdallah al-Abid al-Senoussi's plan to invade Muammar Gaddafi's anti-Zionist regime. ${ }^{84}$ Israel thus progressed from organising Tombalbaye's youth movement to its paramilitary security force, and finally its commando units. ${ }^{85}$

\footnotetext{
${ }^{75}$ M. Denis, Histoire militaire de l'Afrique Equatoriale Française (Paris: Imprimerie Nationale, 1931), pp. $245-437$.

${ }^{76}$ René Lemarchand, 'The politics of Sara ethnicity: a note on the origins of the civil war in Chad', Cahiers d'Études Africaines, 80 (1980), pp. 449-71.

${ }^{77}$ Jacques Foccart and Philippe Gaillard, Foccart Parle: Entretiens avec Philippe Gaillard, Tome 1 (Paris: Fayard, 1995), p. 302.

${ }^{78}$ Service Historique de la Défense (hereafter SHD) 11S130, Wibaux, Rapport de fin de mission, 31 March 1974.

${ }^{79} \mathrm{Al}$ Hadj Garondé Djarma, Témoignage d'un militant du FROLINAT (Paris: l'Harmattan, 2003), pp. 46-8.

${ }^{80}$ Arnaud Dingammadji, NGarta Tombalbaye: Parcours et role dans la vie politique du Tchad (Paris: l'Harmattan, 2007), pp. 154-5.

${ }^{81}$ Commines de Marsilly à Couve de Murville, 2 July 1966, in Documents Diplomatiques Français (hereafter DDF), 1966 (II), Document 85.

${ }^{82}$ Note de la DRAM, 25 January 1968, in DDF, 1968 (I), Document 62.

${ }^{83}$ Samuel Decalo, Israel and Africa, 1956-1996 (Gainesville: Florida Academic, 1998), pp. 49-66.

${ }^{84}$ Dingammadji, NGarta Tombalbaye, pp. 202-10; Roumiana Ougartchinkska and Rosario Priore, Pour la peau de Khadhafi (Paris: Fayard, 2013), pp. 52-7.

${ }^{85}$ SHD 11S130, Wibaux, Rapport de fin de mission, 31 March 1974.
} 
This background, of francophone African leaders urging intervention and Israel threatening France's pre-eminence in Chad, provided the background for French leaders' debates on whether to intervene. Although French policymakers regarded Chad as a quagmire with little intrinsic value, key actors had already concluded that France needed to do more. De Gaulle's Secretary General for African Affairs, Jacques Foccart argued as early as 1967 that, 'Soon we will have to take responsibility for this [Chadian] situation if we want to prevent matters from becoming more toxic. ${ }^{86}$ De Gaulle himself observed in early 1968 that, 'Chad constitutes a section of one wall in our [African] edifice. It is a rotten bit of wall, but it is one that must nonetheless be kept upright. ${ }^{, 87}$ France's debate on whether to intervene came to a head on 25 August 1968 when Tombalbaye invoked the 1960 Franco-Chadian treaty to request military assistance. ${ }^{88}$

France's government initially responded to unrest in Chad by dispatching a senior civil servant. On behalf of de Gaulle, Foccart, took the initiative of replacing the career diplomat representing France with a special ambassador better qualified for Chad's burgeoning civil war in January 1968. ${ }^{89}$ This special ambassador, Fernand Wibaux, a Foccart loyalist, had developed expertise in clandestine operations while in the French Resistance. Wibaux, in turn, determined that France needed to act militarily when Tubu rebels encircled the Chadian Army garrison at Aozou. He advocated a short, swift operation to save the Aozou garrison as a means of shoring up Tombalbaye's regime and reassuring France's other African ex-colonies. ${ }^{90}$ France's Joint Military Staff under General Michel Fourquet, however, opposed intervening and argued that Chad could become a quagmire. ${ }^{91}$

France's cabinet weighed Wibaux's and Fourquet's recommendations and sided with Wibaux, ordering a company of French paratroops to break the rebel siege of Aozou. De Gaulle personally specified that this intervention 'will have a limited duration and we cannot envision stationing our forces permanently in Tibesti'. ${ }^{92}$ The paratroops were quickly dispatched and accomplished their mission in two weeks without suffering casualties. A token force of five French counterinsurgency aircraft - piston-engined Skyraiders - then deployed to northern Chad to deter further rebel attacks as the paratroops withdrew. ${ }^{93}$ These actions, however, failed to improve Chad's security, which paradoxically deteriorated even faster as a result of France's intervention. The Aozou garrison, indeed, mutinied and abandoned their post rather than remain once the siege had been lifted. ${ }^{94}$

This act of indiscipline emboldened rebels throughout Chad. Rebel ranks soon swelled to 2,330 personnel who launched 227 attacks during the first half of 1969 alone. ${ }^{95}$ Rebel forces with soaring morale, yet poor armaments began defeating Chadian forces in conventional engagements, repulsing the government's 'Mokofi' offensive in January 1969 and annihilating a quarter of Chad's gendarmerie in March. ${ }^{96}$ France's handful of attack aircraft failed to arrest this dynamic because pilots failed to spot rebels on the ground and Chadian soldiers proved unskilled at guiding them by radio. ${ }^{97}$

Wibaux responded to these events by lobbying for another limited intervention. Calculating that French forces could quickly destroy FROLINAT's ill-equipped guerrillas in central Chad,

\footnotetext{
${ }^{86}$ Jacques Foccart, Journal de l'Elysée - I: Tous les soirs avec de Gaulle (1965-1967) (Paris: Fayard, 1997), p. 618.

${ }^{87}$ Foccart and Gaillard, Foccart Parle, p. 306.

${ }^{88}$ Ibid., p. 305.

${ }^{89}$ Author's interview with Fernand Wibaux, Paris, 12 November 2004.

${ }^{90}$ Jacques Foccart, Journal de l'Elysée - II: 1968-1969 (Paris: Fayard, 1998), p. 17.

${ }^{91}$ Ibid., p. 37.

${ }^{92}$ Note de la DRAM, 2 septembre 1968, in DDF, 1968 (II), Document 173.

${ }^{93}$ Sébastien Guillemin, Les Skyraider Français (Outreau: Lela Presse, 2012), pp. 281-4.

${ }^{94}$ SHD 11S130, Wibaux, Rapport de fin de mission, 31 March 1974.

${ }^{95}$ SHD 11S133, Bulletin de Renseignements, 31 August 1969.

${ }^{96}$ Les Interventions Militaires Françaises au Tchad (hereafter IMFT), T.1, p. 221.

${ }^{97}$ Guillemin, Les Skyraider Français, p. 286.
} 
Wibaux paved the way for a concerted civil-military effort to consolidate the Chadian government's control over Chad's most populous and prosperous provinces. Wibaux's renewed calls to intervene met with persistent hostility from the Joint Military Staff. Two civilian policymakers, Foccart and Cooperation Minister Yvon Bourges, travelled to Chad on the government's behalf to assess the situation and rallied to Wibaux's point of view. ${ }^{98}$ De Gaulle and his cabinet validated this delegation's assessment and began organising France's military intervention. It was thus on the basis of civilian policymakers' judgements and against military objections that France deployed forces.

\section{Organising the intervention}

Having elected to deploy combat troops, France's government endowed Wibaux with proconsular power to manage all of the intervention's political and military components. While Wibaux's elevation guaranteed civilian supremacy on the ground in Chad, the government further limited the armed forces' autonomy by clearly distinguishing between the campaign's military and administrative aspects. Authority over counterinsurgency activities was invested in two distinct bodies: combat forces under a Military Delegation (DM) and a civilian-run Mission for Administrative Reform (MRA). While a military officer led the former institution, a civilian functionary controlled the latter.

Although such a division of labour may appear straightforward, counterinsurgencies notoriously blur distinctions between civil and military activities. France's government, therefore, defined the MRA's role as broadly as possible and the DM's as narrowly as feasible. It was the MRA that consequently was given the lead role in: increasing Muslims' representation within Chad's administration, re-empowering traditional rulers, digging village wells, and building schools. France's government even granted the MRA authority over Chadian paramilitary forces, which the DM desperately wanted to control because of the role that such indigenous forces played in the military's counterinsurgency doctrine. ${ }^{99}$ French policymakers, in short, entrusted the MRA with managing the 'hearts and minds' campaign central to defeating Chad's insurgents. Thus, although force was deemed essential for achieving France's objectives, the armed forces would be monitored and circumscribed via institutional arrangements privileging civilian authority. ${ }^{100}$

De Gaulle's advisors took great care to select pliant field commanders in addition to institutionally circumscribing the armed forces' role. One of France's most distinguished soldiers, General Marcel Bigeard, had already been promised command of African operations. ${ }^{101}$ However, Bigeard was both a media icon because of his exploits in Indochina and Algeria and an adherent to the counterinsurgency doctrines that had proven so toxic to civil-military relations. ${ }^{102}$

The French cabinet feared that Bigeard would operate too autonomously and therefore handpicked another commander. This officer, Brigadier-General Michel Arnaud, was judged more amenable to political directives and less popular with the media. The French government emphasised the DM's subordinate role in its instructions to Arnaud declaring that, 'The place you occupy in the French military hierarchy in Chad makes you the "military adjutant" to France's ambassador. Your job is to suggest to the Ambassador means for obtaining a given objective and giving the orders necessary for a mission's accomplishment upon the Ambassador's request. $^{\text {,103 }}$

\footnotetext{
${ }^{98}$ IMFT, T.1, p. 222; Foccart, Journal de l'Elysée - II: 1968-1969, p. 647.

${ }^{99}$ SHD 11S140, Activité de la M.R.A., 16 June 1969.

${ }^{100}$ Author's interview with Ambassador Fernand Wibaux, Paris, 18 February 2005.

${ }^{101}$ SHD 11S130, Mémoires (Cortadellas), pp. 6-7.

${ }^{102}$ Foccart, Journal de l'Elysée - II: 1968-1969, pp. 435, 647.

${ }^{103}$ SHD 11S140, Instruction secrète pour le Délégué Militaire, March 1969.
} 
These command arrangements initially satisfied all parties. Upon arriving in Chad, Arnaud used his French forces (1,390 personnel in mid-1969) as a strike force to destroy rebel concentrations. He ordered two Foreign Legion companies to eradicate guerrilla bands in Guera province. The rebels' overconfidence after repeatedly defeating poorly-trained Chadian forces led them to commit the fatal error of attacking the Legionnaires, which led to its comprehensive defeat in 24-9 April 1969. ${ }^{104}$ This victory psychologically stunned the rebels, who became less aggressive throughout central Chad. However, the Foreign Legion's success created problems of its own. Rebels now eschewed contact with French forces, which in turn lacked the numbers to oblige rebels to fight. ${ }^{105}$

French forces' inability to bring rebels to battle soon generated friction between Arnaud and his civilian superiors. Arnaud planned to establish a web of village militias as per the French doctrine of progressively extending quadrillage across a territory. Wibaux, for his part, considered militias and other irregular forces indispensable to both Chadian administrators' authority and reestablishing traditional rulers' authority. ${ }^{106}$ He therefore subordinated militias to the civilianrun MRA rather than Arnaud's command. ${ }^{107}$ Arnaud excoriated this arrangement for undermining his ability to enact the action lente considered so essential to counterinsurgencies. Worse still from Arnaud's perspective, Chadian administrators and rulers employed the militias provided by the MRA to bully villagers. ${ }^{108}$

Arnaud's relations with other members of the Franco-Chadian military committee deteriorated during the summer of 1969 over both the militia issue and other command decisions. ${ }^{109}$ His proposal to withdraw garrisons from two northern prefectures, for example, alienated both Tombalbaye and Wibaux, who worried about the psychological implications of 'ceding' territory to the rebellion. ${ }^{110}$ Arnaud then clashed with Tombalbaye and Chadian commanders over Chadian forces' use of indiscriminant violence, which Arnaud argued drove more Chadian villagers to join the rebellion. Arnaud thereafter lobbied for greater authority over Chadian units. Matters reached a climax when General Arnaud and President Tombalbaye publicly shouted at one another after Tombalbaye advocated massacring 15,000 pro-FROLINAT villagers in August 1969. ${ }^{111}$

Arnaud's poor relations with the MRA and the Franco-Chadian military committee prompted Wibaux to obtain his removal on 8 August $1969 .{ }^{112}$ Wibaux dramatically demonstrated the predominance of civilian over military authority with this act. While Arnaud had quarrelled with his civilian and Chadian counterparts, he had done so on behalf of the Army's cherished counterinsurgency principles and international human rights law.

Within this context, Arnaud's drive to control Chadian paramilitary forces reflected his desire to replicate the military-dominated command structures of past counterinsurgencies. The French armed forces' internal investigation concluded as much, finding Arnaud's conduct irreproachable. ${ }^{113}$ The fact that French political authorities relieved Arnaud under such circumstances demonstrated their willingness to punish commanders for the mere act of disagreeing with their political superiors. French commanders, within this context, only enjoyed the freedom to enact their favoured tactical recipes, such as quadrillage, so long as they did not conflict with civilian policymakers' vision for how to accomplish France's objectives.

\footnotetext{
${ }^{104}$ SHD 11S130, Compte Rendu du Général Magendie, 6 July 1969.

${ }^{105}$ IMFT, T.1, pp. 313-14.

${ }^{106}$ Robert Buijtenhuijs, Le Frolinat et les révoltes populaires du Tchad, 1965-1976 (La Haye: Mouton, 1978), pp. $219-25$.

${ }^{107}$ SHD 2S61, 'La participation des populations à la pacification', 4 June 1969.

${ }^{108}$ SHD 11S130, Compte Rendu du Général Magendie, 29 August 1969.

${ }^{109}$ SHD 2S61, Le DMT au CEMA, 4 June 1969.

${ }^{110}$ Pierre de Tonquédec, Face au Darfour (Paris: Lavauzelle, 2010), p. 11.

${ }^{111}$ SHD 2S61, Rapport de Fin de Mission du Général Arnaud, n.d.

${ }^{112}$ SHD 2S61, Ministre de la Défense au général Fourquet, 8 August 1969.

${ }^{113}$ SHD 11S130, Compte Rendu du Général Magendie, 29 August 1969.
} 


\section{Fighting and negotiating}

Brigadier-General Edouard Cortadellas succeeded Arnaud as France's military commander. Although Cortadellas was, like Arnaud, a veteran of Indochina and Algeria, the conditions of his appointment chastened him to the point that he never challenged his political superiors' authority. However, Arnaud's clashes with the MRA and his Chadian counterparts had revealed management shortcomings in France's counterinsurgency. Wibaux and Cortadellas therefore created two institutions to facilitate a comprehensive counterinsurgency effort: a Franco-Chadian General Staff to improve inter-military collaboration and a civil-military general staff to promote cooperation between the DM and MRA. ${ }^{114}$

These new institutions promoted more effective cooperation between French civil and military actors and between the French and Chadian components of France's counterinsurgency. Moreover, Wibaux's incessant requests for more military support drove France's government to send reinforcements, doubling France's contingent to 2,851 personnel with 34 aircraft by late $1969 .{ }^{115}$ France, meanwhile, also agreed to fund the Chadian army's expansion from 1,900 to 4,300 personnel. ${ }^{116}$ Wibaux and Cortadellas then replaced Chadian field commanders, whom they considered unqualified, with 610 French officers and non-commissioned officers, sending the Chadians on a two-year officer training programme. ${ }^{117}$ French and Chadian forces' strength and management therefore improved rapidly in early 1970.

Wibaux continued to dominate French strategy despite the arrival of Cortadellas and reinforcements. Simply put, French forces would clear an area of insurgents, after which regular Chadian forces would deploy and the MRA would establish paramilitary units. These lower-quality forces would then prevent insurgents from returning to the area as the MRA reinstalled traditional rulers and reformed local administration. French authorities hoped to pacify Chadian regions one by one in this way, starting with economically productive regions near Chad's capital and then shifting to poorer and more peripheral regions. ${ }^{118}$

Franco-Chadian forces consequently launched successive offensives in Guera, Chari Baguirmi, Ouaddaï, and Salamat provinces between October 1969 and June 1970. ${ }^{119}$ The MRA established sixty more village militias and reinstalled the Sultans of Ouaddaï and Sila in their traditional domains in these offensives' wake. ${ }^{120}$ Having distributed 2,410 firearms to paramilitaries, more Chadians were now fighting with the French than against them. ${ }^{121}$ As soon as paramilitary forces detected rebel bands, horse-mounted paramilitaries, and motorised Chadian units converged from multiple directions. In this manner Franco-Chadian forces decimated one rebel band after another, thereby pacifying central Chad by July $1970 .^{122}$

Successes in central Chad were, however, offset by developments in northern Chad. Gaddafi's new regime in Libya raised new perils for Tombalbaye. Gaddafi prioritised ejecting Israel from Chad as soon as he came to power in September 1969, but his colleagues in Libya's Revolutionary Command Council (RCC) opposed overtly intervening. ${ }^{123}$ Revelations in June 1970 about Prince Abdallah al-Abid al-Senoussi's plans to invade Libya with Israeli assistance

\footnotetext{
${ }^{114}$ SHD 2S61, Le Secrétaire d'Etat aux Affaires Etrangères à Ambassadeur Wibaux, 16 April 1970.

${ }^{115}$ Jacques Foccart, Journal de l'Elysée - III: 1969-1971 (Paris: Fayard, 1999), pp. 94, 116-19; IMFT, T.1, pp. $243-4$.

${ }^{116}$ SHD 2S61, Le DMT au CEMA, 26 October 1969; SHD 11S141, Projet de 'Reorganisation des Forces Tchadiennes', 4 December 1969; IMFT, T.1, pp. 265-6.

${ }^{117}$ SHD 2S61, le CEMA au DMT, 30 October 1969.

${ }^{118}$ SHD 11S130, Mémoires (Cortadellas), pp. 76-8.

${ }^{119}$ SHD 11S141, Les opérations pendant la saison sèche, 7 November 1969; SHD 2S61, Concours apporté par la M.R.A., 26 January 1970.

${ }^{120}$ SHD 2S61, Concours apporté par la M.R.A., 26 January 1970; IMFT, T.1, pp. 236-7.

${ }^{121}$ SHD 11S130, Mémoires (Cortadellas), p. 101.

${ }^{122}$ Ibid., p. 100.

${ }^{123}$ The National Archives (hereafter TNA) FCO 39/633, D. A. Gore-Booth to A. J. Sindall, 30 December 1969.
} 
from Chadian territory, however, then convinced Libyan leaders to support Chad's insurgents. $^{124}$

Libya's government immediately deployed its two most reliable infantry battalions to the Chadian frontier to intimidate Chad's government and then began supplying rebels with Second World War vintage armaments. ${ }^{125}$ More importantly, Gaddafi obliged six hundred Tubu veterans of Libya's recently abolished Royal Guard to join their rebel kinsmen in northern Chad and recruited another 150 expatriate Chadians and trained them to fight for FROLINAT. ${ }^{126}$ Gaddafi's infusions of fresh blood and armaments transformed the struggle in northern Chad that had been languishing with only four hundred rebels. ${ }^{127}$

The emboldened Tubus now launched offensives against four objectives: Fada, Zoui, Zouar, and Bedo. While the Tubus failed at Zoui and Fada, they won psychologically significant victories at Zouar and Bedo. Rebels defeated a Chadian Army unit near Zouar in June and then blockaded Zouar's garrison in September. ${ }^{128}$ Slightly thereafter, on 11 October, another Tubu band ambushed French paratroops, killing 12 and wounding $15 .{ }^{129}$ Coming in quick succession, these reverses stunned French policymakers. Cortadellas, indeed, admitted that 'The situation is entirely new and extremely grave. I no longer possess either the numeric superiority, firepower advantage or mobility to deal with more than one trouble spot at a time ... I have lost the initiative and can only hope to react.' ${ }^{130}$

Rebels dominated northern Chad even after a hastily assembled relief column broke the siege of Zouar in late October and a heliborne force destroyed a rebel supply base at Goubone. ${ }^{131}$ Cortadellas, therefore, pleaded for reinforcements to mount a decisive counteroffensive. ${ }^{132} \mathrm{He}$ envisioned elite forces launching rapid successive anti-guerrilla sweeps in France's Army's best tradition of action vive. Cortadellas anticipated that coming to grips with elusive Tubu rebels would be difficult, but expected that his heliborne infantry and motorised columns could maintain a high enough operations tempo long enough to erradicate them. ${ }^{133}$ Wibaux and Foccart, however, only aimed to coerce Tubu rebel leaders into negotiating a settlement. They, therefore, approved preparations for an offensive whose duration and aims were far more limited than Cortadellas desired. ${ }^{134}$

France's government consequently sent reinforcements and materiel for two months for France's largest offensive, codenamed Bison. Cortadellas attempted to use the 1,250 soldiers (900 French and 350 Chadian), 150 vehicles, 18 helicopters, 8 attack aircraft, and 1,600,000 liters of stockpiled fuel at his disposal to crush the Tubu rebels beginning on 10 January $1971 .{ }^{135}$ Operation Bison's very size backfired by convincing rebels to hide rather than fight. During the offensive's first phase (Bison Alpha), the targeted rebel band (150 combatants) escaped detection. During the next phase (Bison Bravo), French forces located twenty rebels, but suffered two dead and five wounded in their haste to engage them. ${ }^{136}$

\footnotetext{
${ }^{124}$ TNA FCO 39/633, A. Abbott to West Africa Department, 14 August 1970.

${ }^{125}$ TNA FCO 39/633, A. Abbott, Arms for Chad, 8 December 1970.

${ }^{126}$ C. Grégoire, Tchad: Borkou-Ennedi-Tibesti, 1970-1972 (Paris: Mémoires d'Hommes, 2004), pp. 171-4.

${ }^{127}$ SHD 11S133, Bulletin de renseignements, 31 August 1969.

${ }^{128}$ Gérard Vuitteney, Trente-deux ans d'aventures parachutistes et coloniales (Paris: Mémoires d'Hommes, 2006), pp. 120-

${ }^{129}$ IMFT, T.1, pp. 321-3.

${ }^{130}$ SHD 2S61, le CEMA au DMT, 15 October 1970.

${ }^{131}$ Jean Dominique, 'Fin octobre 1970: Coup de main héliporté sur Goubone', in Jean-Pierre Chastanet (ed.), Le GCCP-CPIMa (Paris: Mémoires d'Hommes, 2009), pp. 152-7.

${ }^{132}$ SHD 11S140, le CEMA au Ministre de la Défense, 13 October 1970.

${ }^{133}$ SHD 11S140, Etude sur une operation à mener au Tibesti, 1 October 1970.

${ }^{134}$ Foccart, Journal de l'Elysée - III: 1969-1971, pp. 461-71.

${ }^{135}$ SHD 11S140, Opération Bison, 19 December 1970.

${ }^{136}$ SHD 11S140, EMA, Opération Bison, 4 February 1971.
} 4 . 
The Tubu's traditional leader, the Derdeï, announced at this point his willingness to negotiate provided that France agreed to a ceasefire. Cortadellas, for his part, strongly opposed a ceasefire, arguing that further operations would defeat the Tubus outright. ${ }^{137}$ The cabinet, however, overruled Cortadellas and imposed a 'negotiating pause' on 12 February. The Derdeï, though, duplicitously dragged out negotiations to provide rebels the opportunity to either conceal themselves amongst the local population or flee deeper into the mountains. French forces consequently failed to locate rebels when they renewed their offensive (Bison Charlie) after the Derdeï broke off negotiations. ${ }^{138}$

France's largest offensive in Chad consequently failed after neutralising only 16 rebels out of a thousand active in northern Chad. ${ }^{139}$ Cortadellas therefore cancelled the planned follow-on operation to pacify northern Chad with locally recruited paramilitary forces before it had even begun. France's heavy consumption of materiel meanwhile left French forces temporarily unable to conduct intensive operations. The Bison offensive had indeed consumed 2,400,000 liters of fuel and wore wheeled vehicles down to the point that they were discarded.

Worse than the offensive's material results were its psychological ramifications. French elite forces' failure to defeat Tubu rebels consequently discouraged Chadian officials, who had hitherto nourished an exaggerated faith in the efficacy of French arms. ${ }^{140}$ Cortadellas's efforts to apply the French counterinsurgency practice of action vive to northern Chad thus foundered upon civilian officials' more limited objectives and their ability to curtail the Army's offensive. The Defense Ministry's own internal study later reflected on Cortadellas's reduced authority, observing 'The commander of the intervention was not ... a proconsul in the way commanders in Hanoi and Algiers had been .... Although he retained some autonomy ... it was nothing compared to that enjoyed by his predecessors during past wars.' ${ }^{141}$

\section{Stabilisation and disengagement}

The upsurge of Tubu attacks in 1970 and Operation Bison's failure in early 1971 confronted French policymakers with a new state of affairs. Rather than confidently anticipating the rebellion's collapse, political leaders now recognised that obtaining decisive victories would be prohibitively expensive. Major figures within France's government, including Foreign Minister Maurice Schumann, feared increased casualties and argued for withdrawing French forces in July 1971, despite the worsening security situation. ${ }^{142}$ Cortadellas and other commanders, however, argued that more offensives would maintain the initiative and gradually wear down the guerrillas. President Pompidou steered a middle course between these alternatives of precipitous withdrawal and an open-ended commitment to victory by decreeing that he would withdraw from Chad before France's 1973 legislative campaign. Pompidou entrusted Wibaux with laying the groundwork for France to withdraw without undermining its broader African alliances.

Wibaux achieved this by refocusing France's military and administrative efforts on central Chad, and its diplomacy on depriving the rebellion of external support. Wibaux concluded after months of indecisive operations in Borkou, Ennedi, and Tibesti that French forces could not rapidly vanquish the rebellion in northern Chad. Tubus were superlative guerrillas and their nomadic lifestyle rendered them difficult to control. The obstacles to pacifying northern Chad were, however, exceeded only by the region's poverty. ${ }^{143}$

\footnotetext{
${ }^{137}$ SHD 11S130, Wibaux, Rapport de fin de mission, 31 March 1974.

${ }^{138}$ IMFT, T.1, pp. 329-36.

${ }^{139}$ SHD 11S140, Presentation de l'Opération Bison, 15 June 1971.

${ }^{140}$ Jackie Neau, L'Intervention de la France dans le conflit tchadien, 1969-1975 (Paris: Mémoires d'Hommes, 2006), pp. $89-90$

${ }^{141}$ IMFT, T.1, p. 362.

${ }^{142}$ Gustave Jourdren, La Fin du Regime du President Tombalbaye: Le Tchad de 1969 à 1975 (Paris: CHEAAM, 1988), p. 31.

${ }^{143}$ Grégoire, Tchad, pp. 44-7.
} 
Wibaux argued that France should abandon all of northern Chad except the urban centres of Fada, Largeau, Zouar, and Bardaï. France would use the resources economised in the North to consolidate control over Chad's most productive regions, termed le Tchad utile (useful Chad) in the centre. French diplomacy would, meanwhile, strive to deprive insurgents of external sanctuaries. ${ }^{144}$ Wibaux oversaw the MRA's and DM's implementation of this strategy and Cortadellas, for his part, redeployed most French military units from northern to central Chad after reluctantly abandoning airmobile operations against Tubu guerrillas after a final assault in June $1971 .^{145}$

The French military's final act in northern Chad was a massive logistics convoy that transported stockpiles of food and equipment large enough to sustain the Chadian Army's four northern bases for six months. Wibaux prohibited further operations - even potentially promising ones - that might escalate hostilities. France needed its forces in central Chad even though the withdrawal from northern Chad emboldened Tubu rebels and discouraged the region's progovernment populations. ${ }^{146}$

French intelligence was tracking Libyan efforts to reanimate the rebellion in central Chad. Although France had suppressed the revolution in central Chad by mid-1970, Gaddafi helped central Chadian rebels regain the initiative by smuggling arms and material to their camps in Sudan's Dharfur province. Gaddafi also permitted FROLINAT to use Radio-Tripoli's powerful transmitters to broadcast propaganda throughout Chad and Sudan. ${ }^{147}$ Over 1,000 FROLINAT guerrillas were armed and ready to attack from Sudan by early 1972. FROLINAT's leaders planned to invade central Chad with four large camel caravans that would establish liberated areas and recruit new guerrillas. ${ }^{148}$

Wibaux, however, was forewarned by French intelligence and preemptively deployed the DM's and MRA's resources. The MRA played the preeminent role, expanding its paramilitary forces, such that over one hundred village militias guarded central Chad by late $1971 .^{149}$ To win peasant support, the MRA also drilled 146 village wells and built 21 schools. ${ }^{150}$ In a country as poor as Chad these measures secured the neutrality, if not support, of much of the local population. French administrators used these developments and paramilitary initiatives to convince four hundred rebels from the Moubi ethnic group to change sides. France's entire military contingent and Chad's best units stood poised behind the MRA's village-level structures ready to annihilate any rebel bands detected. The French, meanwhile, also deployed radio jammers to disrupt FROLINAT's propaganda broadcasts. ${ }^{151}$

French precautions had thus transformed central Chad into a well-prepared trap before FROLINAT attacked in February 1972. French and Chadian forces detected all four rebel caravans between 18 February and 9 March. Regular military units pursued, engaged, and shattered the rebels in each case. ${ }^{152}$ Once defeated, small rebel groups sought food and refuge in Chadian villages. Village militias however either slaughtered or drove these survivors into the bush. Ultimately, nearly 60 per cent (six hundred rebels) of FROLINAT's Sudan-based guerrillas perished in this ill-conceived campaign. ${ }^{153}$

French policymakers conducted a diplomatic campaign to deprive the rebellion of external support in parallel with Wibaux's efforts in central Chad. Foccart early on convinced the

\footnotetext{
${ }^{144}$ SHD 11S130, Wibaux, Rapport de fin de mission, 31 March 1974.

${ }^{145} \mathrm{Neau}$, L'Intervention de la France, pp. 147-55.

${ }^{146}$ Grégoire, Tchad, pp. 239-41.

${ }^{147}$ SHD 11S130, Mémoires (Cortadellas), pp. 181-98.

${ }^{148}$ IMFT, T.1, pp. 345-9.

${ }^{149}$ SHD 11S130, Mémoires (Cortadellas), p. 183.

${ }^{150}$ Neau, L'Intervention de la France, p. 93.

${ }^{151}$ Grégoire, Tchad, p. 254.

${ }^{152}$ IMFT, T.1, pp. 347-53.

${ }^{153}$ SHD 11S130, Mémoires (Cortadellas), pp. 195-203.
} 
mercurial Central African Republic leader Jean-Bedel Bokassa to extradite FROLINAT supporters in January $1970 .{ }^{154}$ French diplomats then frenetically negotiated with Sudan and Libya. A breakthrough occurred in April 1972, when Sudan's dictator Jaafar Nimeiri ordered his army to massacre four hundred Chadian rebels based on his territory. ${ }^{155}$ Foccart, then, through Nigerien President Hamani Diori's mediation, convinced Gaddafi to cease supporting Chadian rebels in exchange for Chad expelling Israeli advisors and ceding de facto control over territories on the Chado-Libyan border. ${ }^{156}$

France's cabinet unobtrusively withdrew French forces from Chad in August 1972, well before France's upcoming legislative elections, after establishing Chadian governmental control over central Chad and diplomatically isolating FROLINAT. ${ }^{157}$ The Franco-Chadian counterinsurgency campaign had inflicted 5,100 casualties in exchange for 39 French killed and 102 wounded, and 629 Chadian military casualties. ${ }^{158}$ The rebellion consequently collapsed in central Chad and was extirpated from its foreign sanctuaries. France's government conducted a public relations campaign to convince domestic and international audiences that these accomplishments amounted to victory. $^{159}$

Field commanders, however, knew that the rebellion's strength was undiminished in northern Chad where Chadian security forces were still unable to operate effectively. ${ }^{160}$ Foccart, furthermore, anticipated that Gaddafi would soon renege on his commitments. While France's intervention saved Tombalbaye's regime, it stopped short of defeating FROLINAT and therefore ensured that Chad's civil war would continue. Northern Chad's Tubu rebels capitalised on this situation soon after France's withdrawal and gradually overwhelmed the state's armed forces, seizing Chad's capital in 1978, catalysing events that necessitated further French interventions. ${ }^{161}$

\section{Continuity and change}

A French motorised column races across a rugged Sahelian desert to do battle with nomadic guerrillas. The year is 2013 and the country is Mali. To the untrained eye this scene uncannily resembles those that unfolded in Chad four decades previously. The similarities between France's interventions in this conflict and the preceding one are, moreover, more than aesthetic. France's political leaders compelled General Bernard Barrera to push forward and conclude operations faster than he was comfortable with, just as they had with Cortadellas. In Barrera's own words, 'From the operation's beginning, the Executive [President] and [Defense] Ministry strongly pressured the Armed Forces' Chief of Staff and his deputy in charge of operations to accelerate, always going further and faster. This translated into orders to liberate Malian cities faster than our logistics allowed us.' ${ }^{, 162}$

Nonetheless, the four intervening decades of technological progress between these operations reshaped French practices, even though strong continuities are apparent. France's armed forces meanwhile recovered the prestige that they had lost in Indochina and Algeria, while public confidence in political leaders waned. This section therefore examines how these dynamics impacted French leaders' management of African interventions. As will be shown, France's political leaders continue to impose their preference for strategic satisficing, but increasingly rely on new

\footnotetext{
${ }^{154}$ Foccart, Journal de l'Elysée - III: 1969-1971, p. 204.

${ }^{155}$ SHD 11S130, Wibaux, Rapport de fin de mission, 31 March 1974; Jourden, La Fin du Regime du President Tombalbaye, pp. 29-30.

${ }^{156}$ Claude Faure, Aux Services de la République (Paris: Fayard, 2004), pp. 586-7.

${ }^{157}$ Jourden, La Fin du Regime du President Tombalbaye, p. 31.

${ }^{158}$ IMFT, T.1, pp. 358-9.

${ }^{159}$ Grégoire, Tchad, pp. $297-8$.

${ }^{160}$ Ibid., pp. $297-334$.

${ }^{161}$ Buijtenhuijs, Le Frolinat et les révoltes populaires du Tchad, pp. 269-97.

${ }^{162}$ Bernard Barrera, Opération Serval: Notes de guerre, Mali 2013 (Paris: Seuil, 2015), p. 146.
} 
communications technologies to supplement proconsular ambassadors as their means for imposing that preference.

Technical means for steering interventions in real time did not yet exist during de Gaulle's era. It was thus in the Chadian intervention's immediate aftermath that France began building a network of high-powered, high-frequency (HF) radio transmitters across Africa. ${ }^{163}$ This grid known as l'Organisation Mondiale Interarmées des Transmissions (OMIT) - featured both permanent stations and mobile units that could be deployed wherever needed. ${ }^{164}$ Even though OMIT did not permit voice communication, it provided political leaders for the first time with the ability to control operations from Paris in real time. The limits of this system, which remained incomplete until the late 1970s, prompted France to invest in communications satellites, deploying a network of three Syracuse satellites between 1984 and 1986, which provided consistent coverage of francophone Africa. ${ }^{165}$

President Valéry Giscard d'Estaing became the first to use new communications tools to direct an intervention, when France intervened to halt Sahrawi nomads, fighting for the POLISARIO movement and the Western Sahara's independence, from raiding Mauritania's iron ore trains in 1977. Mauritania's immense size prompted Giscard to rely primarily on air power, in the form of fighter-bombers dispatched to Senegal. In an echo of the Chad intervention, Foccart's successor, René Journiac, dispatched Wibaux to Dakar to oversee the operation at a strategic level. Giscard and his inner circle, however, introduced an additional level of political-military complexity because they combined their tactic of airstrikes in Mauritania with negotiations with POLISARIO in Algeria. ${ }^{166}$ To best coordinate these far-flung air strikes and negotiations, Giscard insisted on approving each attack from Paris via a combination of OMIT transmitted HF messages and telephone communications. ${ }^{167}$

Despite technical glitches, Giscard's direction of Mauritanian air strikes yielded swift results, deterring further POLISARIO raids after three precise strikes. This successful experience of micromanaging operations from Paris encouraged Giscard to apply the same techniques when France re-intervened in Chad the following year. This time in Operation Tacaud, the French government combined the appointment of a civilian proconsul, Ambassador Louis Dallier, with the president's direction of operations from Paris. In principle, the HF liaison linking the Defence Ministry's Operations' Centre to the military headquarters in Chad offered faster communications with Paris than the Embassy, where the ambassador received general instructions from Journiac. Leaders in Paris used these two systems to fashion France's use of force.

The coexistence of two channels of command, however, proved deeply problematic when two Chadian factions turned upon one another in early $1980 .{ }^{168}$ As the crisis unravelled, Journiac instructed Ambassador Dallier that French forces should adopt a neutral posture. Giscard, however, opined to the French military's chief of staff, General Guy Méry, that France should align itself with Hissène Habré's faction, which appeared more powerful. Méry therefore used HF communications to order France's field commander, General Louis Forest, to facilitate Habré's victory by allowing his forces to pass through French roadblocks. ${ }^{169}$ Dallier's and Forest's contradictory orders confused lower-level commanders and French forces' inconsistent behaviour convinced all Chadian factions of their duplicity. ${ }^{170}$

\footnotetext{
${ }^{163}$ Frédéric Fogacci et al., De Gaulle et la Défense de la France d'Hier à Aujourd'hui (Paris: Nouveau Monde, 2017 ), p. 57.

${ }^{164}$ Colonel Spartacus, Opération Manta: Tchad, 1983-1984 (Paris: PLON, 1985), pp. 43-4.

${ }^{165}$ Jérôrome de Lespinois, L'Armée de Terre Française de la défense du sanctuaire à la projection T.2 (Paris: l'Harmattan, 2001), pp. 551-8.

${ }^{166}$ SHD 3K4 26, General Guy Méry.

${ }^{167}$ Michel Forget, Nos forces aériennes en Opex: Un demi-siècle d'interventions extérieures (Paris: Economica, 2013), pp. 23-34.

${ }^{168}$ Robert Buijtenhuijs, Le Frolinat et les guerres civiles du Tchad (1977-1984) (Paris: Karthala, 1987), pp. 114-22.

${ }^{169}$ IMFT, T.2, pp. 264-7.

${ }^{170}$ Ibid., p. 265.
} 
French leaders' use of nearly instant communications grew during France's next African intervention. During Operation Manta - France's 1983-4 intervention in Chad - political leaders insisted on steering even minor military actions from Paris. One French colonel observed, 'By expressing their exaggerated belief in "sophisticated" communications, [political] authorities clearly indicated their desire to "pilot the crisis". No latitude is left to Manta's commander. $\mathrm{He}$ is not a general entrusted with a command, but instead an orderly tied to a telegraph.171

The OMIT network that French leaders relied on at this stage was, moreover, woefully inadequate for how they used it. OMIT messages generally took ten minutes to cypher and transmit, and a response could, at best, be expected thirty minutes later. ${ }^{172}$ Delays such as these proved catastrophic during fast-moving crises, such as occurred when Libyan-backed forces attacked the Chadian Army at Oum-Chalouba in September 1983. France's field commander, General Guichard, rapidly concluded that only air strikes could salvage the situation. He needed, however, political leaders' assent for such strikes. Between transmission delays and the time needed for the message to reach the President or Defence Minister, it took 65 minutes for Guichard to receive permission to launch air strikes. By this point, however, the battle of Oum-Chalouba was already over, won in extremis by France's allies. ${ }^{173}$

Even when commanders like Guichard received orders in a timely manner, those orders were crafted by a process that privileged political and diplomatic considerations over military ones. Admiral Jacques Lanxade, who led France's armed forces late in the Mitterrand administration, lamented this mode of crisis management. According to Lanxade, civilians decided matters of crucial importance in so-called 'crisis cells' organised at France's Foreign Ministry. ${ }^{174}$ Within these cells, 'Discussions are dominated by civilian staff members from the Foreign and Defence Ministries, and the Prime Minister's Office .... When military officers are invited, they are generally of a rank too low to influence decisions. ${ }^{, 175}$

Politicians' use of new communications technologies to steer interventions from Paris was not however a consistent or unidirectional process. Politicians can and did privilege civilian proconsuls over long-distance micromanagement on occasion. President Jacques Chirac, for example, empowered a special ambassador when French forces intervened amidst army mutinies and attempted coups in the Central African Republic (CAR) in 1996-7. In his personal instructions to Jean-Marc Simon, a diplomat with considerable conflict experience, Chirac told Simon, 'You could demand a more prestigious post, but we need you there [in the CAR]. You will be, all at once, our governor, our general, our diplomat, and above all my friend. ${ }^{176}$ Once in Bangui, Simon comported himself as Chirac directed, shaping military operations and brokering agreements between warring factions.

Even as French leaders juggled the opportunities provided by new communications technologies with the institutional tools de Gaulle developed for managing interventions, France also experienced a prolonged upsurge in the armed forces' popularity. Public approval for France's military arguably reached its nadir in the early Fifth Republic, following the military's repeated interventions in politics and 'lost' wars. Public approval for the military, however, soared since the 1990s. Opinion polls, consequently, reveal that public confidence in France's armed forces climbed twenty points in two decades. ${ }^{177}$ Today, the armed forces enjoy an 82 per cent approval rating and are therefore France's second most popular institution, lagging one point behind hospitals, but significantly outperforming the media or politicians. ${ }^{178}$

\footnotetext{
${ }^{171}$ Spartacus, Opération Manta, p. 50.

${ }^{172}$ Ibid., pp. 47-9.

${ }^{173}$ Ibid., pp. $70-9$.

${ }^{174}$ Jacques Lanxade, Quand le monde a bascule (Paris: NiL, 2001), pp. 295-6.

${ }^{175}$ Ibid., p. 296.

${ }^{176}$ Jean-Marc Simon, Secrets d'Afrique: Le témoignage d'un ambassadeur (Paris: Cherche Midi, 2016), p. 140.

${ }^{177}$ Bénédicte Chéron, Le Soldat Méconnu: Les Français et leurs armées (Paris: Armand Colin, 2018), p. 20.

${ }^{178}$ Ibid., pp. 19-21.
} 
A range of factors are driving this growth in the armed forces' popularity. Receding memories of the Algerian War and the militaries' professionalisation in the mid-1990s have distanced French citizens from their negative associations with the armed forces. A succession of 'popular' interventions - beginning with the 1991 Gulf War and proceeding through peace-making in the Balkans, to conclude with France's intervention in Mali - have all reinforced the military's perceived legitimacy as an expert body striving for the public good in a manner that prior French African interventions had not. ${ }^{179}$ Coming on top of these developments, the military's domestic counter-terrorism deployment, Operational Sentinelle, following the 2015 Paris terrorist attacks drove the military's popularity to its current stratospheric levels. ${ }^{180}$

The armed forces' increasing popularity and high operational tempo have empowered military officers to increasingly express their discontent with national defence policy. ${ }^{181}$ Armed forces chief of staff, General Pierre de Villiers, did this most publicly with his critiques of the government's low level of defence spending. ${ }^{182}$ As Grégory Daho demonstrates, the combination of public esteem and operational experience is also eroding the pre-existing 'taboo' of military officers positively evoking French doctrine and accomplishments during the Algerian War. ${ }^{183}$ Despite French commanders' increasing willingness to publicly express themselves, their activism has not as yet altered how France intervenes in Africa.

A key reason for this that de Gaulle's formula for managing foreign interventions depends on institutions that circumscribe the military's domain of competence and pit military commanders against one another in parallel chains of command, rather than an assumption that individual commanders behave meekly. Moreover, French military leaders have accustomed themselves to working through these institutions and are justifiably satisfied with the level of activism that they permit. Strategic satisficing, in other words, permits France to intervene more frequently than other states of a similar size and French officers are proud of that. General Benoit Pugo, who served as President François Holland's personal chief of staff, lauded this system in the following terms, 'The decision-making process permits the president to rapidly bring together all essential actors and then give orders directly to military commanders. It's the best [process] in the world. ${ }^{184}$ France's most recent major African intervention, Operation Serval in Mali, therefore demonstrates strong continuities with prior African interventions in its management.

Political leaders, within this context, implemented a combination of new technology-based and older personnel-based techniques for shaping operations. President Holland sacked the career diplomat representing France and replaced him with a specialist 'crisis manager' in an echo of de Gaulle's dispatch of Wibaux to Chad. France's new ambassador in Bamako, Gilles Huberson, possessed formidable credentials for overseeing an intervention having served as a military officer before embarking on a diplomatic career and having managed the Foreign Ministry's Mali-Sahel counter-terrorism assistance programme immediately prior to this appointment. ${ }^{185}$

Defence Minister Jean-Yves Le Drian soon, however, disabused colleagues of the notion that either Huberson or France's field commander, General Barrera, would play the primary role in shaping France's intervention. Le Drian, indeed, organised a so-called 'war room' around his personal cabinet that decided most important matters at meetings organised up to three times a day. Civilians dominated these meetings and most of the invited military officers represented intelligence agencies. ${ }^{186}$

\footnotetext{
${ }^{179}$ Grégory Daho, La transformation des armées: Enquête sur les relations civilo-militaires en France (Paris: Maison des sciences de l'homme, 2016), pp. 95-109.

${ }^{180}$ Chéron, Le Soldat Méconnu, pp. 108-06.

${ }^{181}$ Ibid., pp. $48-54$.

${ }^{182}$ Pierre de Villiers, Servir (Paris: Fayard, 2017), pp. 125-62.

${ }^{183}$ Grégory Daho, 'The erosion of the Algerian taboo: an alternative explanation for the transformation of military organisations in France', Revue Française de Science Politique, 64:1 (2014), pp. 57-78.

${ }^{184}$ Pierre Servent, Les Présidents et la guerre, 1958-2017 (Paris: Perrin, 2017), p. 392.

${ }^{185}$ Isabelle Lasserre and Thierry Oberlé, Notre guerre secrète au Mali (Paris: Fayard, 2013), pp. 191-2.

${ }^{186}$ Ibid., pp. $184-5$.
} 
President Holland, meanwhile, relied on his private military staff to monitor operations and issued orders directly to field commanders via his personal chief of staff, General Pugo. ${ }^{187}$ The armed forces' headquarters and professional military planners, meanwhile, felt marginalised. One general confided to journalists that the military's leadership felt relegated to a 'second class' position. ${ }^{188}$

The upshot of this civilian-dominated process was a plan with all of strategic satisficing's hallmarks. France would quickly smash al-Qaeda in the Islamic Maghreb's (AQIM) larger units, convincing African allies of France's continued great power status, and then expeditiously hand over responsibility for reconquered territories to an African peacemaking force. Central to this plan were the twin notions that French forces could rapidly 'break' AQIM and that African troops would suffice, with minimal support, for subsequent pacification duties. Military commanders, however, harbored reservations about both assumptions. General Barrera, for example, felt pressured to maintain an excessive operational tempo. ${ }^{89}$ Many military officers, meanwhile, doubted whether African states would provide either the quantity or quality of troops needed. ${ }^{190}$

In practice, France's intervention in Mali evinced strategic satisficing's strengths and weaknesses. France retook the cities that AQIM had seized and then assaulted the jihadists' bastions in northeastern Mali in a 100-day campaign. Combined arms battles inflicted hundreds of casualties and French forces captured over two hundred tons of arms and munitions, losing only six French soldiers in the process. ${ }^{191}$ Better still, the French organised democratic elections in August 2013, while insurgents were still reeling from these blows. The speed and seeming completeness of France's triumph convinced many abroad that France possessed some form of sublime savoir faire when it came to African interventions and led institutions, such as America's RAND Corporation, to examine France's experience for transferrable lessons. ${ }^{192}$ The enemy, however, often evaded encirclements and lived to fight another day.

These fighters soon reemerged to harry Malian and African forces once French combat troops withdrew. Morale plummeted amongst the Malian soldiers, leading observers to conclude that France was failing to reconstitute Mali's armed forces. Jihadist attacks on African peacekeepers, meanwhile, exacted a heavy toll, killing over 150 soldiers by early $2018 .{ }^{193}$ Mali's deteriorating security situation since Operation Serval has gotten so bad that writers in the Defense Ministry's journal Défense Nationale now opine that 'If we continue in a spirit of "business as usual" the future will be dark for Mali and the broader region as well. ${ }^{\text {, }}{ }^{2}$

These later operations demonstrate the robustness of de Gaulle's reforms, which put political leaders into the proverbial driver's seat when it came to employing force. Improved communications consequently only reinforced politicians' ability to steer operations. Military commanders' increasing willingness to publicly express themselves, meanwhile, has yet to change this state of affairs. Continuity in whose preferences led, in turn, to further strategic satisficing, with forces of similar size intervening to achieve minimal objectives and thereby setting the stage for France to swiftly hand over responsibility to African forces.

\section{Conclusion}

France's interventions in Africa represent a clear case of policymaking institutions' triumph over the military's deeply held beliefs. At the strategic and operational levels, political and military leaders held diametrically opposed preferences, with the military privileging comprehensive victories

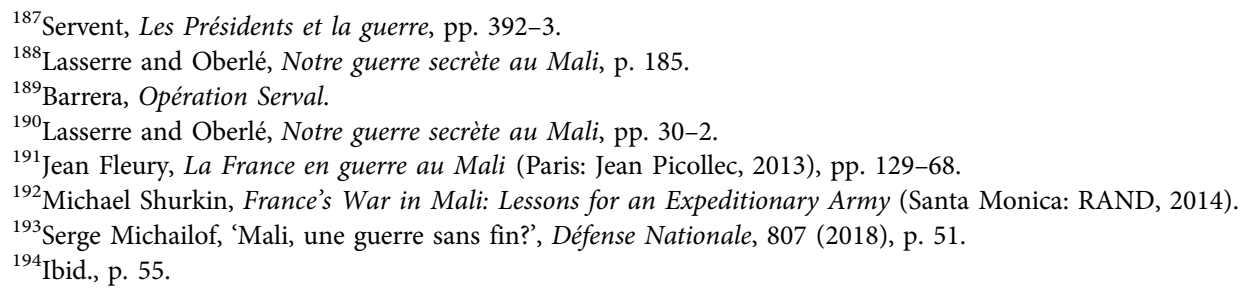


through lengthy campaigns, while politicians sought satisfactory political outcomes through the punctual application of minimal force. The Fifth Republic's new institutions, in effect, empower politicians to impose their preferences on the military. The upshot is strategic satisficing and the close coordination of diplomatic and military initiatives, rather than the preceding era's military dominated efforts to achieve total victory.

These findings, in turn, have powerful implications for our understanding of: (1) military cultures' impact on how states wage war; (2) how military power translates into foreign policy influence; and (3) France's impact on Africa.

A considerable literature has developed about different armed forces' distinctive organisational cultures. My examination demonstrates both the value and limits of such approaches. French officers, indeed, possessed strong beliefs about how counterinsurgencies should be conducted. They therefore sought to apply their pre-existing counterinsurgency templates, such as the classic dichotomy of action lente and action vive, and tactics such as quadrillage, to new situations. Commanders' pursuit of these preferences was, however, strictly circumscribed by new institutions that empowered civilian policymakers to limit military activities whenever they thought doing so would achieve their ends more expeditiously. To the extent that this strict subordination of military desiderata to political control enhances French power, this study supports Douglas Porch's argument that population-centric counterinsurgency's tactical recipes should not be allowed to dictate strategy. ${ }^{195}$

At the same time as constraining commanders, French institutions enable political leaders to impose their preferences. Strategic satisficing - meaning the use of minimal force for short durations to produce satisfactory political outcomes - thus became the new leitmotif of French operations. From a politician's perspective, operating in this manner enabled France to sustain its African sphere of influence without over-committing itself to such a degree as to catalyse a domestic backlash. They therefore exploited the institutional tools at their disposal to relentlessly push the military to conclude operations as soon as possible and limit France's commitment to the lowest possible level. The lower domestic political costs that leaders pay to intervene abroad arguably renders France's military power more fungible - meaning that it provides more international influence - than that of other states with similar material resources.

France's demonstrated willingness to intervene in Chad, indeed, enticed Belgium's ex-colonies to seek military accords with France, including Burundi (1969), Congo-Zaire (1974), and Rwanda (1975). ${ }^{196}$ Later French interventions prompted certain ex-British colonies to follow suit, including the Seychelles (1979), Malawi (1980), and Zimbabwe (1997). ${ }^{197}$ French policymakers and scholars have taken to framing this facility for rapid intervention as a national exception. As already mentioned, General Puga characterises this system as 'the best in the world'. ${ }^{198}$ An academic study, for example, recently concluded that 'despite its apparent complexity, it [France's decision-making process] permits a rapid and tailored decision ... this system, as unique as it is, inspires admiration and jealousy amongst our European counterparts. ${ }^{199}$

While France's ability to intervene at minimal cost and risk to itself bolsters its stature, its interventionism often proves less salutary for African partners. France's propensity to deploy only enough force to achieve minimal political objectives rarely ends conflicts. Such was the case in 1969-72. FROLINAT would have won had France not intervened and France's intervention degraded, but did not destroy Chad's rebellion, prolonging that war until 1979. France's parsimonious use of force thus established conditions that necessitated three further interventions, Operations Tacaud (1978-82), Manta (1983-4), and Epervier (1986-2014). Interventions

\footnotetext{
${ }^{195}$ Porch, Counterinsurgency.

${ }^{196}$ Bruno Charbonneau, France and the New Imperialism: Security Policy in sub-Saharan Africa (Aldershot: Ashgate, 2008), p. 62

${ }^{197}$ Ibid.

${ }^{198}$ Servent, Les Présidents et la guerre, p. 392.

${ }^{199}$ Fogacci et al., De Gaulle et la Défense de la France d'Hier à Aujourd'hui, p. 70.
} 
followed similar patterns elsewhere and events obliged France to re-intervene, within five years, after 58 per cent of France's African interventions. ${ }^{200}$

In short, strategic satisficing - an approach far different from traditional French counterinsurgency practices - facilitates the Fifth Republic's military interventionism. The tightly coupled application of military force and diplomacy in pursuit of limited objectives enables an otherwise medium-sized state, France, to serve as Africa's gendarme, intervening in intra-state conflicts and maintaining a network of security agreements with African states. It is questionable, however, whether France's particular style of intervention serves African interests as well as French ones, since France's limited interventions rarely end conflicts.

Acknowledgements. I would to thank the many individuals who provided advice, feedback, and material throughout this article's development. I would like to begin by thanking the European Journal of International Security's two anonymous reviewers and editorial team for their invaluable feedback. I am also grateful for Maurice Vaïsse for facilitating and advising me during my archival research. I would like to thank the late Ambassador Fernand Wibaux for the many interviews he granted me and his warm hospitality in Paris. I am also grateful to Jacques Duchemin for his interviews and (unattributed) insights on President Tombalbye's regime. I am thankful to Pascal Vennesson, Alain Jacob, and Grégory Daho for discussing this research with me, suggesting relevant literature and, in Vennesson's case, reading an earlier draft. Finally, I would like to thank Audrey DeVore for her feedback through multiple drafts of the project.

Marc R. DeVore is a Lecturer at the University of St Andrews' School of International Relations. Dr DeVore also served as National Security Advisor to the President of the Central African Republic and an advisor to the President of Guniea-Bissau. He is a graduate of France's Institut des Hautes Etudes de Defense Nationale. He has published in the Review of International Political Economy; Security Studies; New Political Economy; Journal of Strategic Studies; Defence and Peace Economics; War in History; and Terrorism and Political Violence. He has conducted field research in the Balkans, Libya, Iraq, Lebanon, and the Central African Republic.

${ }^{200}$ See Table 1.

Cite this article: DeVore, M. R. 2019. Strategic satisficing: Civil-military relations and French intervention in Africa. European Journal of International Security 4, 163-189. https://doi.org/10.1017/eis.2019.1 